\title{
The Innovative Use of Biblical Traditions for Ritual Power: The Crucifixion of Jesus on a Coptic Exorcistic Spell (Brit. Lib. Or. 6796[4], 6796) as a Test Case
}

\begin{abstract}
In this paper, I explore the creative use of biblical traditions in so-called "magical" texts through a detailed analysis of the crucifixion tradition on Brit. Lib. Or. 6796(4), 6796, a seventh-century CE spell for exorcism. I examine three overlapping ways in which the practitioner interacts with the crucifixion story: selection and arrangement of pre-existing traditions; invention of new elements of the story; and the juxtaposition of word and image. I then reflect on the implications of the crucifixion tradition in this spell for analyzing the relationship between biblical traditions and metonymy in "magical" texts, more generally.
\end{abstract}

\section{Introduction}

Scholarship on ancient magic over the past couple decades has highlighted the creative and often improvised nature of ancient curative, exorcistic, and protective rituals. ${ }^{1}$ In fact, the ancient "magician" can now be described as a "bricoleur," who creatively collects and synthesizes disparate materials for the concerns at hand. ${ }^{2}$ This revised view of magic and its practitioners represents an important corrective to more conservative portraits of ritual practice, whereby faithful reproduction of preexisting protocols is thought to be absolutely necessary for the efficacy of a ritual performance. ${ }^{3}$ Yet, despite this recent trend in scholarship to emphasize the practitioner's more artistic side, scholars have yet to appreciate fully the relationship between creativity and the use of biblical and parabiblical traditions for ritual power.

In this essay, I explore the intersections of creativity, biblical tradition, and "magic" during late antiquity through a close examination of Jesus' crucifixion as presented in an early-seventh-century CE Coptic spell for exorcism (Brit. Lib.

1 E.g., Graf 1999, 8; Dickie 1999, 184; Versnel 2002, 129; Gordon 2002, 69-111.

2 Frankfurter 2002, 171. The disparate materials on a given artifact are often unhelpfully associated with language of religious identification. Thus, one can find claims that a single amulet juxtaposes “Christian" and "Jewish" elements (e.g., Hunt 1911, 253; de Bruyn and Dijkstra 2011, 181-82); however, this approach to labeling the elements on amulets imposes foreign categories of religious self-identification onto the amulets (for further discussion, see Sanzo 2014a, 10-14).

3 E.g., Malinowski 1965, 107. 

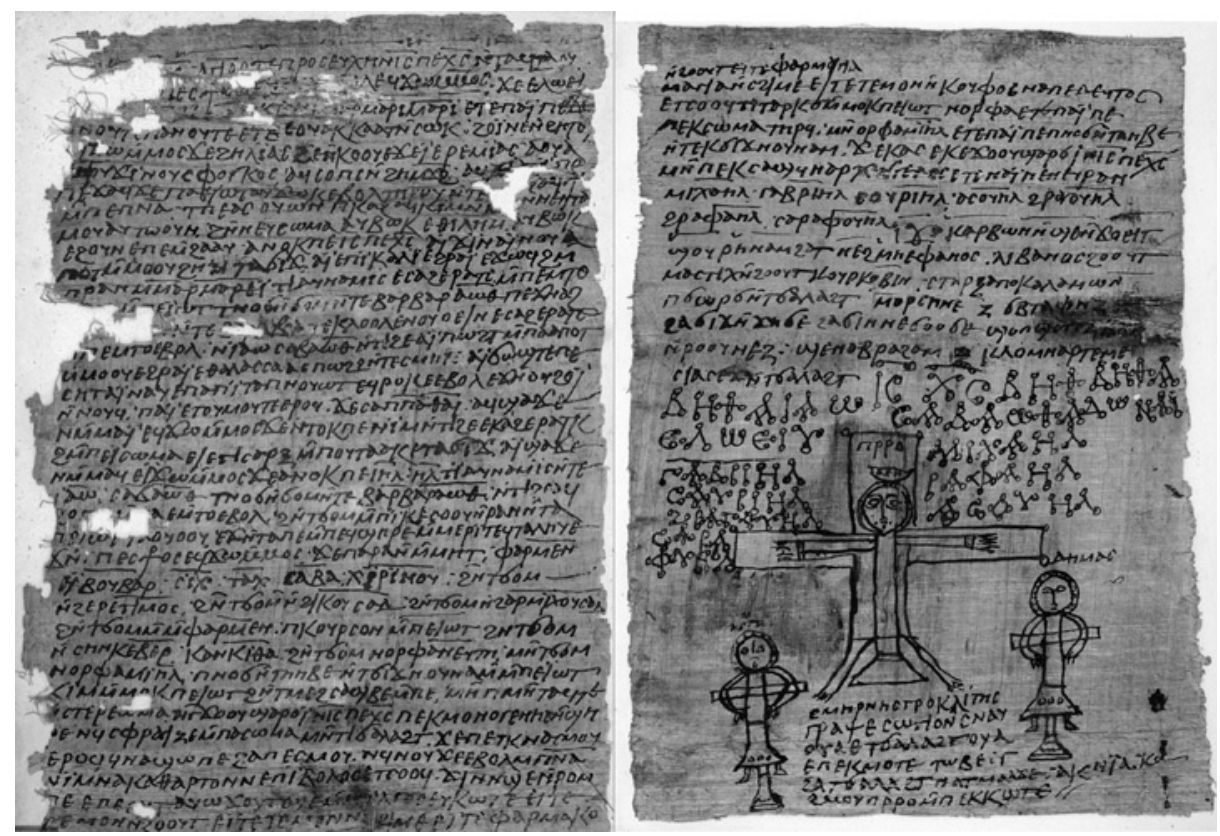

Fig. 1 Brit. Lib. Or. 6796(4), 6796 (Courtesy of the British Library)

Or. 6796[4], 6796). ${ }^{4}$ After offering a brief description of Brit. Lib. Or. 6796(4), 6796, I outline how the practitioner has constructed an innovative tradition of the crucifixion of Jesus. I then argue that this ritual specialist's sustained reflection on the crucifixion provides important insight into the manifold ways biblical traditions were conceptualized and appropriated for so-called "magical” purposes. I further contend that this complexity ought to qualify how scholars of ancient magic understand the relationship between metonymic reference and names of notable biblical characters, especially Jesus.

4 Ed. princ. Kropp 1931a, 47 -50 (J); 1931b, 57-62 (XV). Marvin Meyer has provided an English translation of this spell in Meyer and Smith 1994, 290-92. Photos of the crucifixion drawing on 6796 can be found in Kropp 1930, table 1.1 and Meyer and Smith 1994, 292 (no. 132). For basic descriptions of this spell, see also Meyer and Smith 1994, 277-78; LDAB/TM 100020. On the basis of handwriting, Walter Crum dates this spell to around 600 CE (Kropp 1931a, xi). This spell was designed to cast out (noye) various "demonic" and "magical" threats "...from one hundred years downward and twenty-one miles around (xin nœ) єүк(т़)." For another Coptic spell designed to exorcize demonic forces from an expansive perimeter, see Brit. Lib. Or. 5525 (Kropp 1930, 15 -21; Kropp 1931a, 199-207; Meyer and Smith 1994, 120 24). 


\section{Description of Brit. Lib. Or. 6796(4), 6796}

The Coptic spell under investigation was written across two sheets of papyrus, which are now housed in the British Library-Brit. Lib. Or. 6796(4) and 6796 (see fig. 1). ${ }^{5}$ The first page of the spell, Brit. Lib. Or. 6796(4), measures $34.5 \mathrm{~cm}$ (long) x $24 \mathrm{~cm}$ (wide). It consists of three pieces of papyrus that have been joined, with the fibers running in alternating directions (1l. 1-14 $\rightarrow$; 11. 15-33 $\downarrow$; 1l. 34-37 $\rightarrow$ ). The second page of the spell, Brit. Lib. Or. 6796, measures $34.5 \mathrm{~cm}$ (long) x $25 \mathrm{~cm}$ (wide). This page also consists of three pieces of papyrus that have been joined, again with the fibers running in alternating directions (11. 38-50 $\rightarrow$; 11. 51-60 $\downarrow$; 11. 61-65 $\rightarrow$ ). The text of this exorcistic spell might be usefully divided into eight sections:

1. The Trishagion followed by a prayer of Jesus on the cross (11. 1-10).

2. A discourse between Jesus and a unicorn (11. 10-23).

3. A series of invocations (11. 23-30).

4. An adjuration of the father and various angels (11. 31-45).

5. Instructions for the offering (11. 46-48).

6. Instructions for preparing the ritual bowl (11. 49-52).

7. The drawing of the crucifixion, including names written in "ring-script" (11. 5359).

8. Some final instructions (ll. $60-65)^{6}$

Brit. Lib. Or. 6796(4), 6796 is part of a portfolio of four spells, the other three of which are likewise housed in the British Library: Brit. Lib. Or. 6794; Brit. Lib. Or. 6795; Brit. Lib. Or. 6796(2), (3), (1). ${ }^{7}$ While the style of the handwriting and pictures suggests that a single individual wrote all four spells, each spell was composed for a different purpose. ${ }^{8}$ Brit. Lib. Or. 6794 seems to have been written in order to obtain a good singing voice. In 11. 29-30, we read “...and he (i.e., Davithea) gives me a voice without hoarseness, which does not crack, without roughness, which glides to the heights..."

\footnotetext{
5 Also on the basis of handwriting, Crum implies that these manuscripts may have been from Thebes (Kropp 1931a, xi). LDAB/TM date these manuscripts to the late-fifth or early-sixth century CE (LDAB/ TM 100020).

6 Although this paper is oriented around select portions of Brit. Lib. Or. 6796(4), 6796, I encourage the reader to consult the translation of this entire spell (Appendix 1). It should be noted that, in order to avoid unnecessary confusion, I follow the original line divisions of Kropp 1931a, 49 (also followed by Meyer and Smith 1994, 291).

7 I examined these manuscripts at the British Library on 5-6 August, 2014. For similar collections in Coptic, see the London Hay collection (10122, 10376, 10391, 10414, 10434) and the so-called “Coptic Wizard's Hoard” in the Michigan collection (P. Mich. 593-603, 1294). On the latter, see the analyses of Worrell 1930, 239-62 and Mirecki 1994.

8 Kropp 1931a, xi; Meyer and Smith 1994, 275.

9 Translation by Richard Smith in Meyer and Smith 1994, 280. P. Berlin 8318 and P. Yale 1791 (first text) are also Coptic spells designed for acquiring a good singing voice (see Meyer and Smith 1994, 244-46, no. 121 and Meyer and Smith 1994, 246-48, no. 122).
} 
A musical function for this spell is reinforced by the inclusion of a picture of a figure holding what seem to be bells and a kithara. ${ }^{10}$ Brit. Lib. Or. 6795, on the other hand, is a spell for good fishing; 11. 42-44 of this spell read, "Ordain for me myself, todayme, Severus, son of Joanna-Raphael your archangel, and let him collect every species of fish for [me]..." ${ }^{11}$ Once again, the function of the spell is reinforced by a picture. In the case of Brit. Lib. Or. 6795, there is an image of a man who has successfully caught a fish on a hook, which is attached to a fishing line. ${ }^{12}$ Finally, Brit. Lib. Or. 6796(2), (3), (1), is a prayer to Mary for protection and is likely to be part of a larger Marian "magical" tradition that extended throughout late antiquity and beyond. ${ }^{13}$ Like the other spells, Brit. Lib. Or. 6796(2), (3), (1) includes a picture of a figure (presumably Jesus Christ); however, much of this picture is lost due to a lacuna in the manuscript, and it is thus not helpful in reconstructing the specific occasion for the spell. ${ }^{14}$

It is particularly interesting that, while Brit. Lib. Or. 6796(4), 6796 is a spell that does not specify the name of the client, the other three spells claim to have been written for a single client: "Severus son of Joanna” (Brit. Lib. Or. 6795; Brit. Lib. Or. 6796 [2], [3], [1]), alternatively spelled, "Severus son of Anna" (Brit. Lib. Or. 6794). ${ }^{15}$ That Brit. Lib. Or. 6796(4), 6796 is linked to spells that appear to have been utilized by an actual client named Severus may suggest that this Severus performed the rite prescribed in Brit. Lib. Or. 6796(4), 6796 or used the two manuscripts as an applied exorcistic or protective device; however, it must be stressed that there are no traces of folding-a physical feature that in some cases indicates applied usage. ${ }^{16}$ At the very least, the existence of other texts written by the same ritual specialist assists us in interpreting various elements in the text of Brit. Lib. Or. 6796(4), 6796.

10 Meyer and Smith 1994, 275.

11 Translation by Richard Smith in Meyer and Smith 1994, 282.

12 It is likely that this figure is Jesus, since the nomen sacrum for Jesus is written twice (once on the figure).

13 For other versions of this spell, see P. Heid. Inv. Kopt. 685; P. Iand. Inv. Nr. 9 A B; Coptic Mus. 4958; Brit. Lib. Or. 5987 (ll. 10-12). For discussion, see Meyer 1996; Meyer 2002.

14 In the extant manuscript, the nomen sacrum $\overline{\mathrm{IC}}$ and an alpha are written respectively above and below a figure on the right side of the manuscript. The right side of this picture is fragmentary, but Angelicus Kropp was able to decipher the nomen sacrum $\overline{x c}$ (above) and an omega (below) (Kropp 1931a, 44; cf. Meyer and Smith 1994, 289). It is thus likely that the depicted figure is Jesus Christ. 15 Meyer and Smith 1994, 275.

16 For important qualifications about the relationship between folding and applied amuletic usage, see de Bruyn 2010a, 158-63. 


\section{Innovation and the Crucifixion Tradition on Brit. Lib. Or. 6796(4), 6796}

In this section, I reconstruct the crucifixion tradition in the text of Brit. Lib. Or. 6796 (4), 6796. I focus my attention on three overlapping ways that the practitioner has engaged creatively with the crucifixion tradition. I argue in the second section that this sustained interaction with the crucifixion tradition offers us a vivid picture of the complex ways authoritative traditions were conceptualized and appropriated for apotropaic, curative, and exorcistic purposes. In so doing, Brit. Lib. Or. 6796 (4), 6796 presents a clear challenge to facile mappings of the relationship between biblical traditions and metonymy in formularies and applied ritual devices.

\section{II.1 Innovation through the Juxtaposition of Biblical Texts}

Scholars have long recognized that the "Christian scriptures" were used on amulets and spells for protective, curative, and exorcistic purposes. ${ }^{17}$ In fact, attention to the use of scripture on such artifacts has contributed to the study of various topics, including the nature of ritual language, ${ }^{18}$ shifts in ritual practice through time and space, ${ }^{19}$ and the textual transmissions of the Old and New Testaments. ${ }^{20}$ One observable aspect of ancient practitioners' use of the scriptures, which is important for the present discussion, is that they consistently cited short excerpts of biblical material. ${ }^{21}$ This manifest approach to the scriptures carries significant implications for tracing how ritual specialists understood the textual character of the Bible. Rather than seeing the Bible as a unitary whole, the evidence suggests that they viewed the Bible more like a repository of individual thematic units, only some of which were appropriate for a given situation..$^{22}$ This understanding of the scriptures not only allowed for the extraction of elements from various biblical books, but also facilitated the creative juxtaposition and arrangement of non-contiguous biblical elements with one another. ${ }^{23}$

The first section of Brit. Lib. Or. 6796(4), 6796 appears to exemplify this creative use of biblical materials. The spell begins with the Trishagion followed by a prayer of

17 E.g., Biondi 1979; Judge 1987.

18 E.g., de Bruyn 2010a; de Bruyn and Dijkstra 2011; Sanzo $2014 a$.

19 E.g., Kraus 2005; Brakke 2006, 232; Shandruk 2012.

20 E. g., Biondi 1979; Leonas 1999; Porter 2006, 319-22; Wasserman 2011; Head 2012, 439-43; Jones 2015.

21 See, for instance, the charts of biblical language on amulets in de Bruyn 2010a, 166-89 (reproduced in part in Sanzo 2014a, 53).

22 For a fuller analysis of this view of the scriptures in amuletic contexts, see Sanzo 2014a, 54-69. 23 For the use of collections of biblical texts for divinatory purposes, see The Gospel of the Lots of Mary (Luijendijk 2014a). 


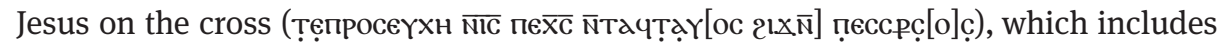
a description of the crucifixion scene and the events surrounding it (ll. 1-10). The prayer reads as follows:

"Elôei [Elôei La]m[a Saba]ktani Marmarimari,"24 that is "God, my god, why have you abandoned me?"25 Some of them [s]aid, "Elias,” others, "Jeremias." One of [t]hem took a sponge and dipped it in vinegar, and he (Jesus) took a taste. He said, "My father, all things have been com[plet]ed," and at once he gave up the spirit. Heaven opened, the earth quaked, and the bo[nes] of those who had d[i]ed arose. In their bodies they went to Jerusalem, and they went (back) into the tomb. ${ }^{26}$

Aside from the use of "Marmarimari,"27 the ritual specialist presents a crucifixion scene that conflates different canonical accounts-albeit with strong ties to the Gospel of Matthew. For instance, the details of the heavens opening, the earth quaking, and the rising and returning of the bones of the deceased in Jerusalem (see Mt. 27:5153) are unique to Matthew's account.

Moreover, the ritual specialist includes material in his Jesus prayer that ultimately derives from another part of Matthew's Gospel. Although both the Gospels of Matthew and Mark record that the crowd interpreted Jesus' use of LXX Ps 21:1 as summoning Elijah (Mt 27:47; Mk 15:35), the particular juxtaposition of "Elias” (Elijah) and "Jeremias" (Jeremiah) does not derive from one of the passion narratives, but from the introduction to Matthew's account of Peter's confession of Christ (Mt 16:13-20). Thus, we read in Mt 16:13-14 that "when Jesus entered the district of Caesarea Philippi, he asked his disciples, saying, 'Who do people say that the Son of Man is?' They said, 'Some (say) John the Baptist; others (say) Elijah; still others (say) Jeremiah or one of the prophets.",28

Yet not all of the biblical language can be traced back to the Gospel of Matthew. Aside from the description of the sponge with vinegar (see Mt 27:48; Mk. 15:36; Lk

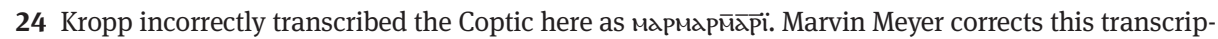
tion error in his translation of this spell (Meyer and Smith 1994, 290).

25 For the use of the words of abandonment (and derivative expressions) on amulets and spells, see Rob. Nahm. Copt. Am., 1l. 31-32; PGM 2,14, 1l. 7-8; Brit. Lib. Or. 5987, 1l. 114, 124; Brit. Lib. Or. 6796 (2), (3, (1), ll. 62-63; Rossi’s “Gnostic” Tractate 9, ll. 17-18; P. Berol. 11347v, l. 12. For a discussion of this phenomenon, see Camplani 2010; Kropp 1930, 128 (§ 218).

26 Meyer and Smith 1994, 290 (trans. Marvin Meyer).

27 In a subsequent section (ll. 11-15), the practitioner describes the closely related name "Marmarthi" as follows: "...in the name of Marmarthi, the force ( great power (бом) of Barbaraôth, the right [forear]m of Baraba, the cloud of light which stands before Iaô Sabaôth.” For the broader context of Marmarimari (and related terms), see Kropp 1930, 124-25, §206 and Pleše 2006, 171.

28 Kropp calls the juxtaposition of the Matthean passion account and the Matthean confession of Peter "sinnlos" (1931b, 61). 
23:36; In 19:29), which does not clearly align with one particular Gospel, ${ }^{29}$ the statement, "My father, all things have been completed," is missing from Matthew's passion account. Instead, this phrase resembles language from the Gospels of John and Luke. After taking the sponge with vinegar, the Johnannine Jesus proclaims, "It is fin-

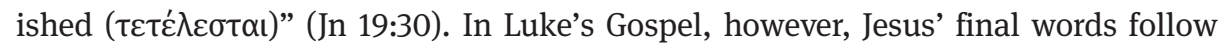
the splitting of the temple curtain. For Luke, Jesus proclaims in a loud voice, "Father, into your hands I commit my spirit” (Lk 23:46).

The crucifixion prayer on Brit. Lib. Or. 6796(4), 6796 is thus a hybrid account of different biblical texts and traditions. It not only recounts a visceral moment in Jesus' incarnational existence, but it also stresses the power associated with that moment to work miracles, specifically to bring the dead back to life. What is not immediately clear, however, is the extent to which this composite account originated with the practitioner. In this vein, it is worth reflecting briefly on "intertexutality" and related concepts in biblical studies.

Biblical critics, especially in the field of Hebrew Bible, have often used the term "intertexuality" as a synchronic reader-oriented approach in which the scholar isolates the origins of the texts without commenting on textual influence. ${ }^{30}$ In cases of "intertexuality," the known use of biblical texts as such is either unlikely or difficult to determine. In other words, "intertextuality" involves the juxtaposition of passages that the scholar-not necessarily the author the scholar is analyzing-recognizes. By contrast, some biblical scholars have deployed the terms "inner-biblical exegesis" and "inner-biblical allusion" to denote diachronic author-oriented models that are used to describe instances in which an author intentionally incorporates texts into his or her work. ${ }^{31}$ These latter models involve at least some level of textual influence. ${ }^{32}$ The use of such concepts to trace various types of relationships between and among texts, authors, and readers raises an important question for the present essay: to what extent does the foregoing exercise of isolating biblical elements in Brit. Lib. Or. 6796(4), 6796 reflect the practitioner's approach to the scriptures?

Indeed, the identification of textual relationships between biblical traditions is challenging not only in the case of the Old and New Testaments, but it is also tricky in the study of late antique Egyptian amulets and spells-albeit for slightly different reasons. On the one hand, the relevant ritual artifacts were created long after the original composition of the biblical texts that they presumably cite. Thus, at least in theory, there is no historical problem with postulating direct textual influence. In addition, the material record attests to the circulation of numerous biblical manu-

29 For the ritual significance of the vinegar, see P. Heid. Inv. Kopt. 685 13.21-24 (Meyer 1996, 32 33).

30 Meek 2014. On “intertextuality,” more generally, see especially Kristeva 1980.

31 For a useful survey of this scholarship, see Meek 2014, 284-90.

32 Meek 2014. Scholars of Paul have also used terms, such as "quotation" and "allusion," to convey the intentional use of a text, while using terms, such as "echoes," to convey unintentional references to texts or traditions (Lucas 2014, 110-11; cf. Hayes 1989). 
scripts in Egypt during late antiquity. ${ }^{33}$ In other words, biblical texts formed an authoritative part of the Christian landscape of late antique Egypt and, accordingly, would have presumably made an impact on Egyptian practitioners. ${ }^{34}$ On the other hand, it was precisely because of their authoritative status that biblical texts were incorporated into other venues, such as the liturgy as well as other amulets and spells. ${ }^{35}$ For this reason, one cannot always be sure if the practitioner was citing a series of texts from the Bible or from one or more other sources, in which clusters of biblical elements were already juxtaposed.

In the case of the Jesus prayer in Brit. Lib. Or. 6796(4), 6796, the lack of a parallel text in the extant record suggests that the biblical tradition here was not received indirectly through an extra-biblical source, such as the liturgy, an apocryphal Gospel, or an amulet. To the contrary, all indications suggest that author was creatively engaging with the text of Matthew (and perhaps other biblical texts)-whether by memory or, perhaps more likely, through examination of one or more manuscripts.

We can, therefore, conclude with a relatively high degree of confidence that the author himself or herself has taken a creative posture toward this biblical tradition. This posture is reflected in the additional reference to the power of God ("Marmarimari"), the interpolation of material from another Matthean pericope, and the use of language, which is reminiscent of Jesus traditions, but which does not easily fit into any one Gospel-canonical or otherwise. Of course, the practitioner participated in a social context that curbed the creative boundaries of his or her biblical elaborations. ${ }^{36}$ Nevertheless, despite the fact that the balance of material seems to have been fashioned in dialogue with biblical texts, the ritual specialist has created a unique version of the crucifixion scene.

\section{II.2 Innovation through Invention}

Through the analysis of Jesus' prayer on the cross (1l.1-10), we have already begun to see the dynamic character of a long-standing and well-established tradition in a ritual exorcistic context. In particular, we observed how the scribe crafted a unique crucifixion scene by juxtaposing different canonical traditions with one another. In the discussion that follows, we will see that, alongside the creative arrangement of

33 See, for instance, Elliott 2000.

34 One cannot assume that amulets and spells that contain "Christian" content were composed by Christian practitioners (see de Bruyn and Dijkstra 2011, 171; Shandruk 2012; Sanzo 2014, 10-14); however, it is likely that at least some practitioners self-identified as Christian, whether they were laity, monks (Frankfurter 1997, 125-30; Frankfurter 2002; Brakke 2006, 226-39), or clerics (cf. the Council of Laodicea, canon 36).

35 This liturgical consideration may be especially important for discussing the use of the Matthean version of the Lord's Prayer on amulets. For discussion and texts, see Kraus 2006.

36 In this vein, Kim Haines-Eitzen is correct in arguing that the discursive practices of Christian churches placed constraints on scribal practices (Haines-Eitzen 2000, 106). 
biblical elements, the practitioner adds his or her own details to the crucifixion scene -a creative approach to sacred tradition already hinted at in the use of Marmarimari, as discussed in the previous section.

In 11. 23-26 of Brit. Lib. Or. 6796(4), 6796, the ritual specialist includes the following invocation: "By $(2 \overline{\mathrm{N}})$ the power of the six other names that the father uttered over the head of his beloved son when he was hanged upon the cross, saying, 'My true name is Pharmen, Eiboubar, Sich, Tach, Saba, Chirinou." While most of these names do not otherwise occur in this spell or in any of the other spells within the portfolio, Pharmen occurs in 1. 28 of Brit. Lib. Or. 6796(4), 6796, in which he is given the title, "the messenger of the father (пкоүрсом $\overline{\bar{M}} \overline{\boldsymbol{\epsilon}} \overline{\boldsymbol{\omega}} \overline{\boldsymbol{T}} \overline{\text { )." }}$

In the invocation of the "six other names," the father participates in the crucifixion scene by proclaiming these sacred names over Jesus' head. What is interesting about this particular detail is that it complicates the crucifixion scene as depicted in Jesus' prayer on the cross (1l. 1-10). Jesus proclaims in that section the words of LXX Ps 21:1 (via the Gospel of Matthew), which highlight the Savior's perceived abandonment by the father during the crucifixion (11. 2-4). Yet, in this passage the father has not abandoned the crucified Jesus, but is near his beloved son (пєчс)нрє мммеріт). Thus, in addition to detailing the names of the father, perhaps this invocation also helps resolve the theological problem of the abandoned Christ through its demonstration of the father's close proximity to his son during the crucifixion.

There is also a section of this spell that appears to reside at the interstices of scriptural juxtaposition and scriptural invention. In 11. 17-23, the practitioner recounts a conversation between Jesus and a "unicorn" (папітдп моүют), which the context suggests was thought to have taken place some time during the crucifixion event. The text reads:

I (Jesus) looked down and saw a unicorn, who was lying on a golden field, the one (the unicorn) who is named Sappathai. ${ }^{37}$ He spoke to me, saying, "Who are you? If thus you stand in this body

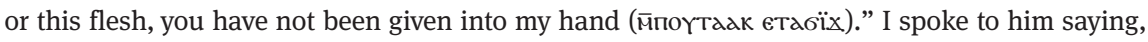
"I am I(sra)êl Êl, the force (Аүмамic) of Iaô Sabaôth, the great power (бом) of Barbaraôth." So he hid himself from before me. ${ }^{38}$

In this exchange between Jesus and the unicorn in Brit. Lib. Or. 6796(4), 6796, the unicorn attempts to take charge over Jesus (cf. the phrase, "мпоүтдак єтдбїх"). Since Jesus wards off the unicorn through the proclamation of his true names and associations, it would seem that, for this practitioner, the one-horned beast was an emissary of Satan.

The practitioner may have selected the unicorn for this role because of the menacing portrait of unicorns in LXX Ps 21, the incipit of which he or she cited (via the

37 For the identification of the "unicorn" as "Sappathai," see n. 103 below.

38 This is a slightly modified version of Marvin Meyer’s translation (Meyer and Smith 1994, 290). 
Matthean tradition) in the opening prayer of Jesus (1. 2-3). ${ }^{39}$ Accordingly, we may be witnessing here in Brit. Lib. Or. 6796(4) an instance of metalepsis (i.e., "a literary technique whereby an author cites, alludes to, or echoes an older text in a newer one and thus draws a connection between the two texts that is...implicit”). ${ }^{40}$ LXX Ps 21:21-22 reads, "Rescue my soul from the sword, and from a dog's claw my only life. Save me from a lion's mouth, and my lowliness from the horns of unicorns

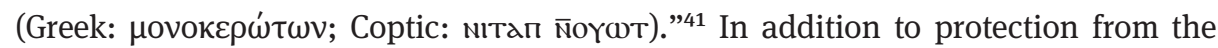
horns of unicorns, the Coptic translation of this psalm-following the Septuagintalso requests protection from the sword, a dog's claw, and a lion's mouth. Of course, it must be conceded that, among the threatening entities mentioned in the psalm, only the unicorn figures in Brit. Lib. Or. 6796(4), 6796. The absence of these other entities in Brit. Lib. Or. 6796(4), 6796 may thus suggest that the practitioner did not derive the detail of the unicorn from LXX Ps 21. Yet the fact that the practitioner conceptualizes the crucifixion scene in close dialogue with the incipit of this psalmalbeit via the Gospel of Matthew-increases the likelihood that there was a connection between the unicorn discourse in Brit. Lib. Or. 6796(4), 6796 and LXX Ps 21:2122. Further reinforcing this explanation is the possibility-and perhaps likelihoodthat the practitioner had access to biblical manuscripts, evident in the initial prayer of Jesus on the cross (see discussion above). If in fact the practitioner intended to draw a connection between the crucifixion narrative and LXX Ps 21:22, then he or she exposes even more acutely than in the Jesus prayer the blurred boundaries between creative juxtaposition of scriptural passages and the invention of new materials. In either case, however, the practitioner has not only expanded the crucifixion narrative beyond the biblical tradition, but he or she has also created an occasion for integrating into the spell the name Iaô Sabaôth-a name that now has built into it precedent for warding off an unwanted entity (i.e., the unicorn). ${ }^{42}$ Such a precedent may stand behind its use in the seventh section of this spell (see discussion below).

39 I am grateful to Richard Kieckhefer for drawing my attention to this possible connection with LXX Ps 21. It should be noted that the association between one-horned animals and the crucifixion of Jesus is not unknown in early Christian literature. For instance, in his treatise against Marcion, Tertullian interprets the patriarch Joseph-who is likened to a one-horned animal (unicornis) in his Latin translation of Deut 33:17 (following the LXX)-as a type for Jesus (Adv. Mar. III.18). For Tertullian, this typological interpretation facilitates a range of symbolic applications (e.g., the single horn as a symbol of Christ's salvation or as a metaphor for the vertical beam of the cross).

40 Lucus 2014, 95. Metalepsis has been the subject of much debate in Pauline scholarship ever since it was introduced into the field by Richard B. Hays (Hays 1989). Hays' use of metalepsis has drawn particularly strong criticism from Christopher D. Stanley and Stanley Porter (for a discussion of these critiques, see Lucas 2014). Alec Lucas has recently attempted to reinstate metalepsis in Pauline studies-though modifying aspects of Hays' initial presentation (Lucas 2014).

41 Translation taken from Pietersma and Wright 2007.

42 For another interpretation of this passage, see Fauth 2014, 71. 
In these two passages, the practitioner of Brit. Lib. Or. 6796(4), 6796 has moved far beyond arranging pre-existing traditions and has invented new details that fill out his or her depiction of the crucifixion. In so doing, the ritual specialist has also established occasions for integrating powerful names of the divine into the spell and perhaps for resolving perceived theological infelicities in the Gospel accounts.

\section{II.3 Innovation through the Juxtaposition of Word and Image}

There is growing recognition among historians of ancient art that the conceptual boundary separating word and image in antiquity was quite porous. ${ }^{43}$ Michael Squire, for instance, has recently demonstrated that the strict delineation between "word" and "image"-with preference given to the former-is rooted in the theology of the Reformation, which drove an influential wedge between verbal content and visual form. ${ }^{44}$ This recent challenge to word and image as discrete categories has allowed art historians to investigate the manifold strategies that ancients deployed to relay information and/or tell stories by juxtaposing verbal and visual data. ${ }^{45}$

With this insight in mind, I will reconstruct the crucifixion tradition as presented in the crucifixion scene on Brit. Lib. Or. 6796 (the second page of the spell [see fig. 1]) by taking into consideration both the verbal and visual elements. By appreciating the complex hermeneutical interplay between words and images in antiquity, we will be able to see how visual and verbal elements in this crucifixion scene complement, expand, and complicate the presentation of the scene itself and the depiction of the crucifixion in the spell as a whole. ${ }^{46}$

On Brit. Lib. Or. 6796 (11. 53-59), the crucified Jesus is placed in the center of the scene with the two criminals flanking him on either side (see fig. 2)-an aspect of the crucifixion narrative that is conspicuously missing from the other sections of the spell. While the tradition of the two crucified criminals can be found in the three synoptic Gospels (Mt 27:38, Mk 15:27, Lk 23:32-43), the names of these criminals cannot. Despite this gap in the canonical tradition, however, the names "Gêstas" and "Dêmas," found here are not unique to Brit. Lib. Or. 6796(4), 6796; rather, the passion narrative in the Gospel of Nicodemus (hereafter GNic) names the faithless criminal "Gestas," and the repentant criminal "Dysmas.” Thus, in GNic 9:5, we read, “...and let Dysmas ( $\Delta \nu \sigma \mu \tilde{\alpha} \varsigma)$ and Gestas (Г'́ $\sigma \tau \alpha \varsigma)$, the two criminals, be crucified with you [Jesus].” Moreover, in GNic 10:2, we learn that:

43 Newby $2007,5-7$.

44 Squire 2009.

45 E.g., Blanshard 2007; Squire 2011.

46 It should be highlighted that the recent work of Squire and other art historians on the diverse strategies taken toward word and image in antiquity (with a particular emphasis on ancient Greece), challenges-or perhaps adds another layer of complexity to-the distinction that some scholars have tentatively drawn between Greek and Egyptian approaches to writing (e.g., Frankfurter 1994). 


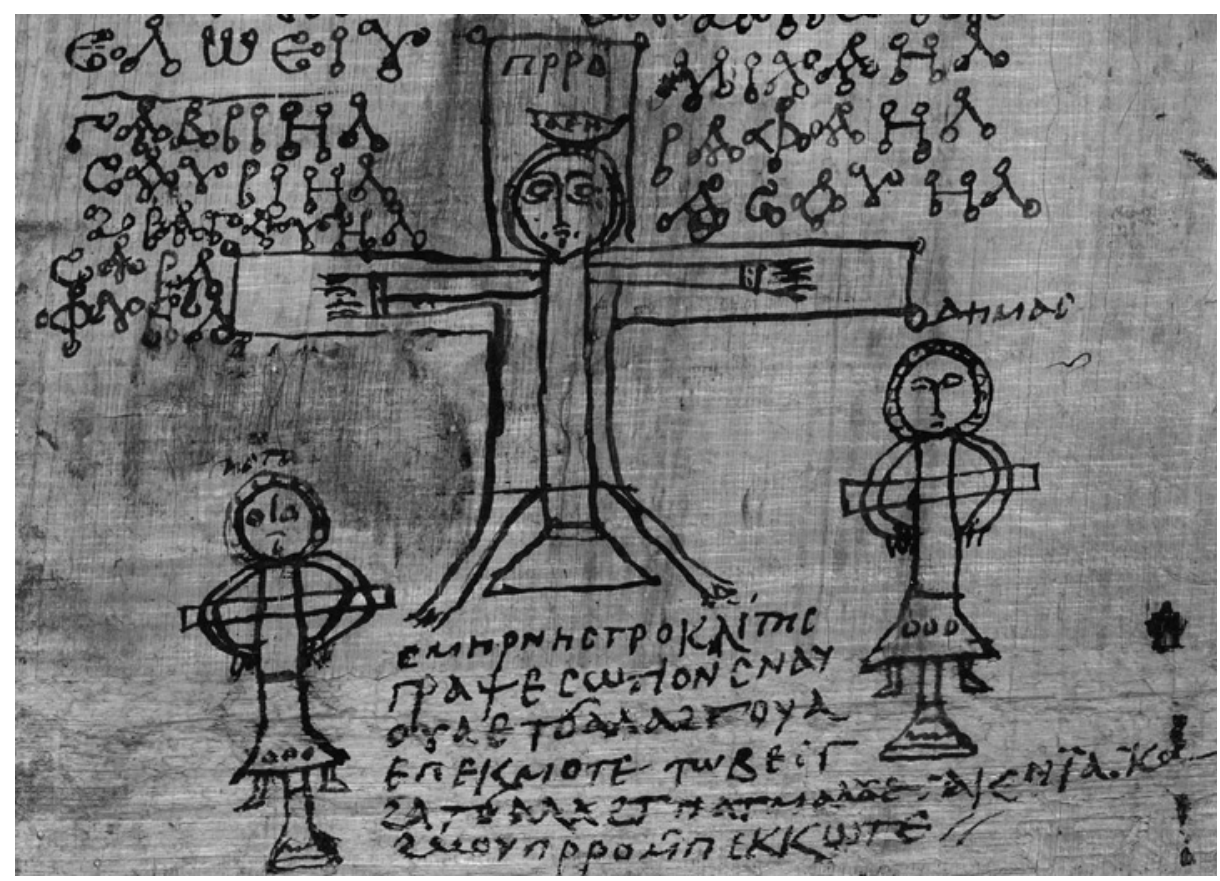

Fig. 2 Brit. Lib. Or. 6796: Images of Gêstas and Dêmas (Courtesy of the British Library)

...one of the criminals (i.e., Gestas)... said to him, "If you are the Christ, save yourself and us." But Dysmas ( $\Delta v \sigma \mu \tilde{\alpha} \varsigma$ ) responded (to Gestas)...'have you no fear of God? ...We deserve our fate, for we are being punished appropriately for our actions. But he did nothing wrong. And he (Dysmas) said to Jesus, "Remember me, Lord, in your kingdom." And Jesus said to him (Dysmas), "Truly, truly, I say to you, today you will be with me in paradise."

In these two passages, GNic does not simply supply names for the repentant and unrepentant criminals from Lk 23:32-43, but this text also incorporates these named characters into the general narrative and dialogical structure of the Lukan version of this story.

To be sure, Brit. Lib. Or. 6796(4), 6796 and the GNic differ slightly on the name of the repentant criminal (Dêmas vs. Dysmas); however, this variant spelling is not surprising given the various forms that these names took in late antiquity. ${ }^{47}$ While direct textual dependence is difficult to establish, we can reasonably assume that, at the very least, Brit. Lib. Or. 6796(4), 6796 and GNic participate in a common written or oral tradition. ${ }^{48}$ This relationship with GNic or a shared tradition may also explain

$47 \operatorname{Kim} 1973,4$.

48 For a fifth-century CE date for the Coptic tradition of GNic, see Vandoni and Orlandi 1966, 7677; Izydorczyk and Dubois 1997. For the view that the Coptic tradition is no earlier than the tenth 
why in Brit. Lib. Or. 6796 the picture of the faithful Dêmas is in an elevated position and is drawn in closer proximity to the picture of the crucified Jesus than that of Gêstas (see fig. 2).

Yet this crucifixion scene offers further interesting details. The inscription on the cross above Christ's head reads прро (“the king"), thus evoking the title of Christ allegedly written on the cross as recorded in all four canonical Gospels (Mt 27:37; Mk 15:26; Lk 23:38; Jn 19:19-22). In addition, the vowels $d \in \mathrm{H}$ are written inside the crown of Jesus. These three vowels were likely to have invoked metonymically the entire sequence of seven vowels, ubiquitous in ancient "magical" literature. ${ }^{49}$ The fortunate preservation of the other spells in this portfolio, however, allows us to fill in more fully the significance of the vowels for this practitioner. For instance, in Brit. Lib. Or. 6796(2), (3), (1), 11. 65-70, we learn that the father created the sea "...th[rou]gh

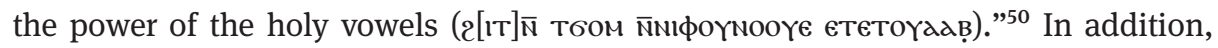
we learn from Brit. Lib. Or. 6794, 11. 40 - 42 that the vowels are branded "on the fa-

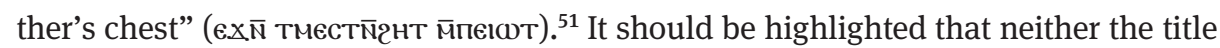
"king” nor the vowel-sequence on Jesus' crown occur anywhere else in Brit. Lib. Or. 6796(4), 6796.

Moreover, the ritual specialist has altered the script that he has used throughout the text, deploying a new script with rings (see fig. 3). ${ }^{52}$ This ring-script resembles a cluster of ringed symbols and signs-which typically correspond to no known alphabet-that scholars call charaktêres. ${ }^{53}$ On Brit. Lib. Or. 6796(4), 6796, the following information is written in this ring-script: Jesus Christ; Bêth Bêtha Bêtha; Iaô Sabbaôth Adônai; Elôeiu; Michaêl, Gabriêl, Raphaêl, Suriêl, Asuêl, Raguêl, and Saraphuêl.

Many of these words have been encountered in the other sections of Brit. Lib. Or. 6796(4), 6796. For instance, aside from the name Jesus Christ, which occurs throughout this spell, we have already seen the name Iaô Sabaôth in Jesus' first-person rebuke of the unicorn (ll. 21-22): "I am I(sra)êl Êl, the force (АүNamic) of Iaô Sa-

century CE, see O'Ceallaigh 1963, 30. If this latter position is correct, Brit. Lib. Or. 6796(4), 6796 may be the first piece of evidence for GNic in Coptic.

49 For discussion, see Cox Miller 1986; Frankfurter 1994, 199-205.

50 Translation by Richard Smith in Meyer and Smith 1994, 284.

51 This same ritual specialist also uses the vowels in the Prayer to Mary in association with a series of names derived from "Marmarimu" (Brit. Lib. Or. 6796[2], 11. 79-80). P. Rylands 103 also utilizes the motif of the vowels being branded on the father's chest (Kropp 1931a, 211-12; Meyer and Smith 1994, 231).

52 Kropp refers to the words in this script as "Zauberbuchstaben” (“magic letters”) (Kropp 1931a, 49).

53 The lexeme charaktêres is an "emic" term that is used for these signs on some ancient artifacts (e.g., PGM VII.193-96). For analyses of charaktêres, see Frankfurter 1994, 206-10; Brashear 1995, 3441-443; Dieleman 2005, 96 -101; Collins 2008a, 73-78; Bohak 2008, 270-74; Gordon 2002, 88-90. An image of P. Mich. inv. 3023a, an amulet from Karanis that deploys charaktêres, is available online at http://www.lib.umich.edu/traditions-magic-late-antiquity/images/07.jpg 


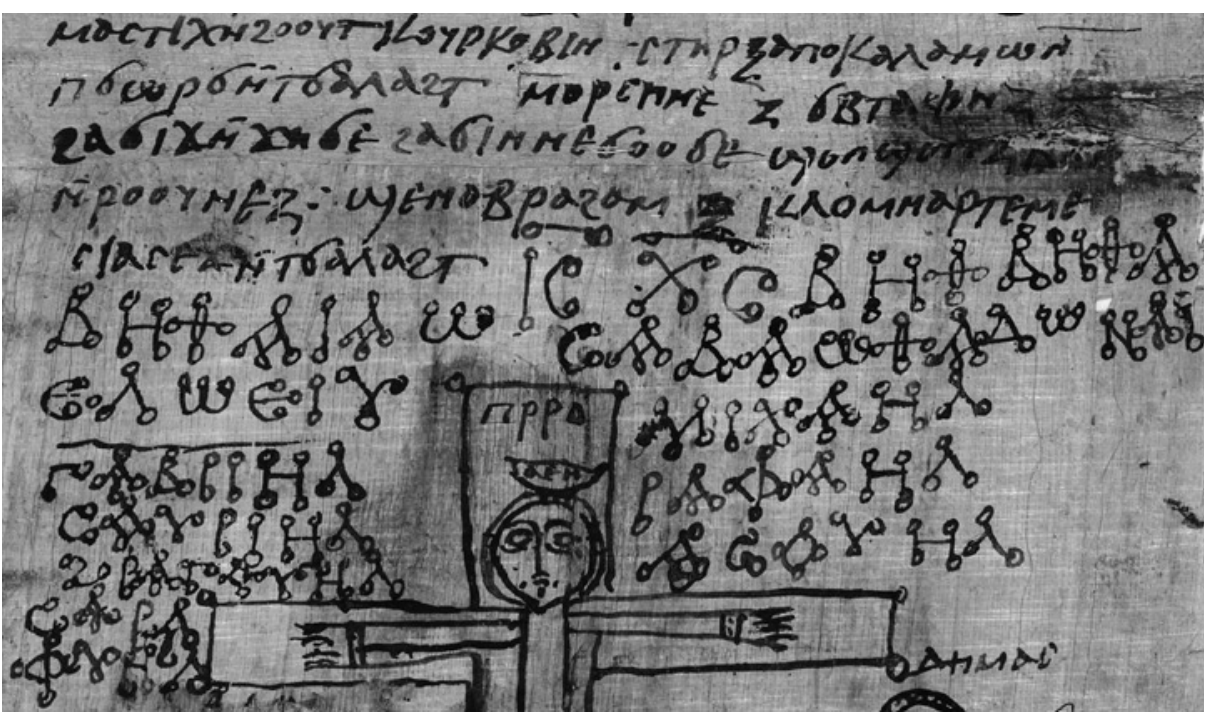

Fig. 3 Brit. Lib. Or. 6796: Transition from "Regular" Script to "Ring-Script" (Courtesy of the British Library)

baôth, the great power (бом) of Barbaraôth." ${ }^{54}$ As I mentioned above, these names have already been successful in warding off an unwanted entity (i.e., the unicorn).

The names of the seven archangels are also found earlier in Brit. Lib. Or. 6796(4), 6796 as part of a request that the father send them to the client (Severus?) along with Jesus: "I adjure you, father, by Orpha, that is your entire body, and Orphamiêl, that is the great finger of your right hand, that you send me Jesus Christ and the seven archangels, whose names are Michaêl, Gabriêl, Suriêl, Asuêl, Raguêl, Raphaêl, Saraphuêl (11. 40 -45)." Despite the earlier reference to these archangels, it is interesting-and perhaps unexpected-that this particular cluster of names above the drawing does not correspond in any way to the six names that the father proclaimed over the head of the crucified Jesus in 11. 25-26 (Pharmen, Eiboubar, Sich, Tach, Saba, and Chirinou).

In addition to the archangels, the word Elôeiu is reminiscent of the words of

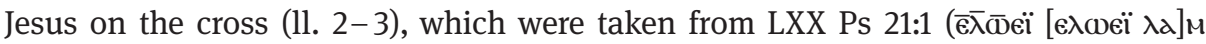
[а сава]к̣та̣! \{ eration, however, I think it is more likely that Elôeiu is a name for god. This same ritual specialist clearly uses Elôei as a name for the "true hidden God" (пмоүтє ммме етгнп) in conjunction with Iaô Sabaôth Adônai (as here) in Brit. Lib. Or. 6796

54 The name Iaô Sabaôth is also found in ll. 14-15 of Brit. Lib. Or. 6796(4), 6796: “...the cloud of light, which stands before Iaô Sabaôth." 
(2), (3), (1), 1. 39: “'O true hidden god, hear me today...They fear [his holy name,

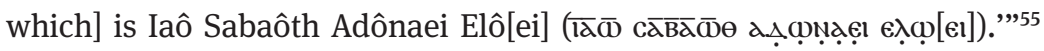

Finally, although the words "Bêth Bêtha Bêtha" are not found anywhere else in Brit. Lib. Or. 6796(4), 6796, Angelicus Kropp is probably correct in suggesting that they are shorthand for the twenty-four elders from the book of Revelation. ${ }^{56}$ Indeed, 11. 43-44 of Brit. Lib. Or. 6796(2), (3), (1) read, “...by the power of the 24 elders, whose

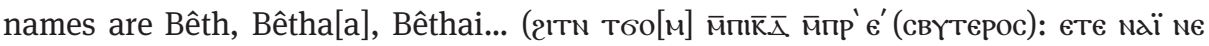

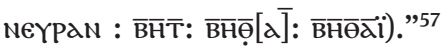

The meanings and significance of the names that are written in this ring-script can thus be identified with a high level of confidence through the internal testimony of Brit. Lib. Or. 6796(4), 6796 and from references in the other spells from this practitioner's portfolio. But an important question remains: why has the ritual specialist altered the script he or she has used throughout the spell and written these names in the ring-script?

In order to answer this question, I think it is instructive to compare the use of the ring-script here with the uses of charaktêres in other late antique ritual texts. One of the most important aspects of charaktêres is their capacity to add a visual dimension to a recipe or applied text..$^{58}$ In fact, given their untranslatable nature, the visual component was the primary means by which these symbols conveyed meaning-albeit in perceived communications with the divine. ${ }^{59}$ Like the charaktêres, the ringscript on Brit. Lib. Or. 6796 also adds a visual dimension to the text; the clear transition from the standard script used throughout the remainder of the text to the ringscript-which is also significantly larger than the standard script-would have been evident to even the most illiterate individual in late antique Egypt. But, contrary to the use of charaktêres, the ring-script on Brit. Lib. Or. 6796 has been used to adorn

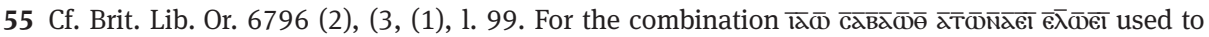

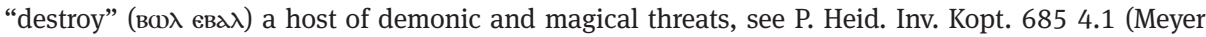
1996, 14). On the use of the words of abandonment as a divine name, see Kropp 1930,128, §218. 56 Kropp 1931b, 62. See, for instance, Rev 4:4, 10-11; 5:8-14; 11:16-18; 19:4. The twenty-four elders are also invoked on a Latin amulet from Egyptian Babylon (P. Heid. L 5; ed. princ. Daniel and Maltomini 1988). In addition, P. J. Sijpesteijn has argued that the twenty-four charaktêres on a Coptic amulet in the Moen Collection may be a reference to the twenty-four elders (Sijpesteijn 1982, 377). 57 See also Brit. Lib. Or. 5525 and P. Iand. 9 A, 1l. 2,9-3,2. P. Heid. Inv. Kopt. 685 invokes the Lord “...by the salvation (of) your 24 bodiless elders, whose names are 'Bêth Bêtha Rouêl... (мпоүхаı $\langle M\rangle$

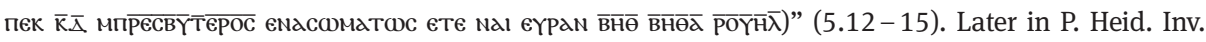
Kopt. 685, the names Bêth Bêtha Bêthanei are associated with the 9 guardians that are to be worn (15.19-24). The names "Bêth, Bêtha, Bêtha” fit within the London Hay "Cookbook" (London Hay 10391, 1l. 2-4) as follows: "Bêth, Bêtha, Bêtha, you three guardians, strong in your power, who guard the body and the blood of the beloved son" (trans. David Frankfurter and Marvin Meyer in Meyer and Smith 1994, 264). On the elders, see Kropp 1930, 83 - 85, §144-47; Meyer 1996, 64-65. 58 Frankfurter 1994, $206-207$.

59 See Dieleman 2005, 97; Wilburn 2012, 72. 
letters that actually spell names known from other contexts. ${ }^{60}$ In other words, the ring-script here is genuinely both "visual" and "verbal" (or "textual”) and, accordingly, blurs the line between word and image on this spell.

Given the visual-verbal nature of the ring-script used on Brit. Lib. Or. 6796 along with the great care taken to fit all the names in ring-script around Jesus' cross, evident especially in the writing of Saraphuêl's name (1. 56), I would argue that these divine and angelic names were not only meant to be read, but were also designed to be viewed within the overall visual depiction of the crucifixion scene. ${ }^{61}$ Whether occasioned by personal piety, a lack of artistic skill, or simply laziness, the ring-script offered a convenient way of incorporating these entities into the visual story of Brit. Lib. Or. 6796 without having to draw them. Indeed, this same practitioner has demonstrated in another spell the unstable boundaries between ringed-writing and drawings.

In Brit. Lib. Or. 6794, the practitioner adorns a picture of a figure (Severus?) holding the musical instruments with a combination of charaktêres, letters written in ring-script, and rings connected to the instruments. ${ }^{62}$ Written in ring-script above

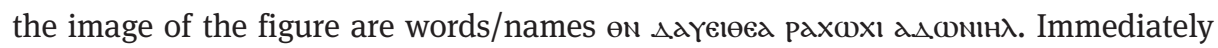
before $\mathrm{en}$ are two charaktêres (one horizontal, the other vertical) that resemble the musical instruments found in the drawing below. Juxtaposed with these words/ names are various letter combinations written in the practitioner's normal script:

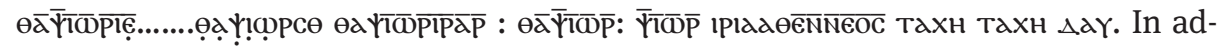
dition to these elements written above the drawing, there are more "traditional" charaktêres found outside and within the image of the figure. What is more, the practitioner adorns his drawing of the instruments with rings on the ends. Thus, in the case of Brit. Lib. Or. 6794, the ringed-elements are not distinct from, but are incorporated into the overall visual scene-albeit in highly complex ways.

If my interpretation of Brit. Lib. Or. 6796 is correct, then, in addition to Jesus, Gêstas, and Dêmas, the tradition of Jesus' untimely end in the drawing on Brit. Lib. Or. 6796 has an additional cast of otherworldly characters: Iaô Sabbaôth Adônai Elôeiu; the seven archangels; and the twenty-four elders. ${ }^{63}$

60 This same ritual specialist also uses the ring-script to spell $\overline{\mathrm{IC}}$ three times on Brit. Lib. 6795 and $\overline{\mathrm{IC}}$ $\overline{x \mathrm{c}}$ on 6796 (2), (3), (1). It is likely that in these contexts, these names are used as labels for Jesus Christ. What is more, this practitioner uses the ring-script for the first letter ( $\mathrm{x}$ ) of Brit. Lib. Or. 6795. 61 For instances of words used visually through miniaturization, see Squire 2011, 3-7. Concerning the juxtaposition of word and image in the Tabulae Iliacae, Squire writes, "[a]s knowingly intermedial objects, they demand at once to be read and to be viewed" (Squire 2011, 127 [emphasis in original]). On the relationship between statues and their inscriptions, Zahra Newby writes, "[w]hile the disappearance of most of the statues leads us to make a distinction between the lost statue and its surviving base, in antiquity both would have been viewed together as a distinct whole...though there could also have been dissonances between the information presented by each" (Newby 2007, 6).

62 For a reproduced drawing of the picture of this spell, see Meyer and Smith 1994, 280.

63 This explanation also helps explain why the ring-script was used for the names of the angels, but the standard script was used for the names of the thieves, who were already incorporated into the 
But we must not think of this picture as a mere representation of the crucifixion and thus only efficacious vis-à-vis an "original” tradition. Recent work on the relationship between representation and reality in ancient "magical" contexts has demonstrated the blurred line that existed between an image or a statue of a given object, on the one hand, and the object itself, on the other hand. ${ }^{64}$ In the words of Andrew T. Wilburn, "[t]he representation can have an effect on reality, as the practitioner mimes or mimics an ideal reality-a reality that he or she has determined-into being." 65 I would argue that, from the perspective of the practitioner, the pictographic "version" of the crucifixion scene on Brit. Lib. Or. 6796 became-at least for the purposes of the ritual-the "real" crucifixion scene and, as such, contained paradigmatic power that could be mediated to the present situation. ${ }^{66}$

To conclude this section, the ritual specialist behind Brit. Lib. Or. 6796(4), 6796 has created a complex account of the crucifixion of Jesus. This unique account (or accounts) and the various forms that it takes cross the conceptual boundaries between word and image, representation and reality, creativity and reproduction, canonical and non-canonical traditions, ${ }^{67}$ orthodoxy and heterodoxy, and religion and magic-not to mention the textual boundaries separating pericopes within the Gospel of Matthew. I will now discuss the implications of this ritual specialist's sustained reflection on the crucifixion for the relationship between authoritative traditions and metonymy in late antique ritual practice.

\section{Brit. Lib. Or. 6796(4), 6796, Metonymy, and the Name Jesus on Amulets and Spells}

The portions of Brit. Lib. Or. 6796(4), 6796, which I have discussed, reveal that the crucifixion of Jesus carried for this practitioner a host of associations-ranging from those known from the literary record (esp. the New Testament [the Old Testament?] and GNic or a related tradition), to those utilized primarily in ritual contexts (e.g., the angelic names, Iaô Sabbaôth), to those that seem to have been (mostly) in-

scene through drawings. It must be conceded, however, that the ring-script is used for $\overline{\mathrm{Ic}} \overline{\mathrm{xc}}$, which seems to function as a label. I think that the ring-script was selected to label Jesus Christ instead of the standard script (cf. the labels for the thieves) on account of the uniqueness of Jesus. What is clear is that, since there are no pictures of the archangels, the names of the archangels, which are written in ring-script, did not function as labels in the strict sense of the term.

64 E.g., Collins 2008a, 92-97; Wilburn 2012, 74-83. For the view that the ritualized animation of statues was an invention of the theurgists (and thus not present in earlier Greek and Roman religious traditions), see Johnston 2008.

65 Wilburn 2012, 77.

66 On the importance of precedent and paradigm for ritual power, see Frankfurter 1995, 465 and the discussion below.

67 This same ritual specialist also juxtaposes the fishing traditions in Lk 5:5 and Jn 21:6 with Tob 6:1-9 in his spell for good fishing (Brit. Lib. Or. 6795, 1l. 5-16). 
vented by the practitioner (i.e., the six names spoken above the crucified Jesus and the discourse between Jesus and the unicorn). ${ }^{68}$ The prolonged reflection on Jesus' crucifixion in Brit. Lib. Or. 6796(4), 6796 demonstrates that, when this author thought of the crucifixion of Jesus for an exorcistic situation, multiple associations with that tradition were evoked, which can ultimately be traced back to multiple sources. As a result, Brit. Lib. Or. 6796(4), 6796 bears witness to a complexity in the ritual use of the "Bible" that I think warrants further scrutiny: associations with a given biblical story often transcended the context of that story and even the pages of the Bible.

In this section, I argue that the crucifixion tradition on Brit. Lib. Or. 6796(4), 6796 acutely demonstrates the highly variable nature-and even the outright unpredictability-of metonymic reference to long-standing authoritative traditions, such as biblical lore, in ritual contexts. To this end, I discuss an aspect of ritual specialization that has yet to receive adequate treatment: the relationship between metonymy and the use of Jesus' name on amulets and formularies.

\section{III.1 The Complexity of Biblical Tradition: Brit. Lib. Or. 6796(4), 6796 and Beyond}

While the lengthy retelling of a particular tradition in Brit. Lib. Or. 6796(4), 6796 exemplifies the complexity of authoritative traditions in ritual practice, this text is hardly anomalous in this regard. For instance, PSI inv. 365, a fifth-or sixth-century CE Greek amulet, also testifies the porous boundaries between canonical and noncanonical Jesus traditions for a healing ritual. ${ }^{69}$ The practitioner explicitly draws on the paradigmatic power of healing traditions of Jesus that are found in the canonical Gospels (i.e., the raising of Lazarus from the dead [Jn 11:1-46] and the healing of Peter's mother-in-law [Mk 1:29-31, Lk 4:38-41, Mt 8:14-15]) and innumerable stories of Jesus' healing ministry outside of the canonical Gospel tradition. Thus, the amulet calls upon "the one who did both the many and ineffable healings beyond those that

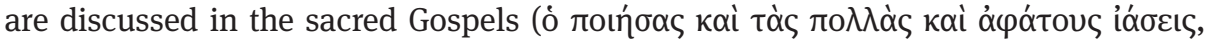

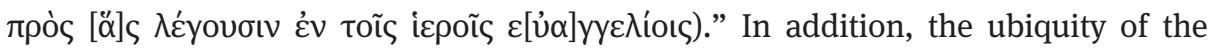
amuletic use of Mt 4:23/9:35, which makes a general reference to the many healings of Jesus in Galilee, may be related to the passage's open-endedness and, hence, capacity for allowing practitioners to invent new Jesus traditions about healing and/or appropriate local non-canonical tales for their rituals. ${ }^{70}$

68 For a comparable interest in the crucifixion of Jesus for "magical" purposes, see P. Heid. Inv. Kopt. $68513.13-14.4$.

69 Ed. princ. Vitelli 1928, 300-301.

70 Sanzo 2014a, 157. The parallel portions of Mt 4:34 and Mt 9:35 read, "And [Jesus] walked about...teaching in their synagogues and preaching the gospel of the kingdom and healing every dis-

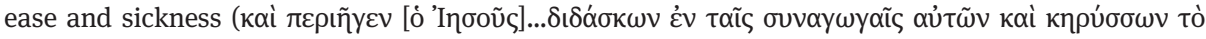

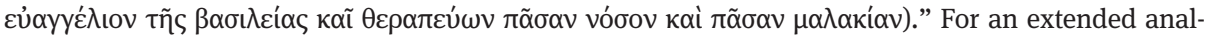
ysis of the amuletic use of Mt 4:23/9:35, see de Bruyn 2008. 
Moreover, that practitioners creatively engaged with webs of cultural associations connected to well-established and authoritative traditions (e.g., biblical lore) is evident from the numerous instances in which practitioners have attributed to famous mythic figures otherwise unknown characteristics or recast such figures in wholly new roles and contexts. Much like the dialogue between Jesus and the unicorn in 11. 17-23 of Brit. Lib. Or. 6796(4), 6796, a sixth-century CE Greek amulet from Egyptian Babylon, P. Heid. 1101, includes the following historiola:

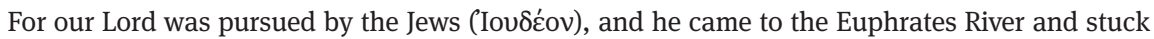
in his staff, and the water stood still. Also you, discharge ( $\dot{\rho} \varepsilon \tilde{v} \mu \alpha)$, stand still from head to toenails in the name of our Lord, who was crucified...(1l. 8-11) ${ }^{71}$

In this amulet, the practitioner invents a new Jesus story and transports Jesus to an entirely new locale (i.e., the Euphrates River). ${ }^{72}$

But this creative and expansive approach to the "Bible" on amulets and formularies must be situated within its broader social context. Indeed, the dynamic character of the Bible was not confined to relics of so-called "magic." "73 For instance, it is well known that the Bible-especially the psalms-played an important role in the quotidian affairs of monks during late antiquity. ${ }^{74}$ Yet, the high authority bestowed upon the Bible and its ubiquity in late antique monasteries did not ensure its hermeneutic stability or even its textual coherence within ascetic contexts. To the contrary, as Douglas Burton-Christie and William Graham have demonstrated, monastic elders had a proclivity for expanding on the authoritative text of scripture, sometimes even prefacing their words with the phrase, "as it was written."75 Moreover, traditions linked to famous ascetics, such as St. Antony and Evagrius of Pontus, either depict

71 Ed. princ. Maltomini 1982. Daniel and Maltomini 1990, 90-96, no. 32. For a discussion of this historiola, see Fiaccadori 1986; Mazza 2007, 444-45; Sanzo 2014 b.

72 This complex tradition of biblical interpretation is related to a phenomenon that John Miles Foley has called, "traditional referentiality," whereby a short reference to a well-known tradition can evoke metonymically a wide range of associations (Foley 1991). For different views on the utility of "traditional referentiality" for the study of the "magical" use of Homeric poetry, see, on the positive side, Versnel 2002, 124 and, on the negative side, Collins 2008a, 108; Collins 2008b, 215.

73 As this point relates to earlier Christian documents, see Hill 2012, 277; Zuntz 1953, $268-69$. 74 The Rules of Saint Pachomius, for instance, require the memorization of the Lord's Prayer and numerous psalms in order to be admitted into the monastery (Praec. 49). For an analysis of the use of the Psalms in the Coptic tradition, see Richter 2003.

75 Graham 1987, 139; Burton-Christie 1993, 109-11. For the relationship between scriptural citation in monastic sayings and contemporary rhetorical and educational trends, see McVey 1998 and Rönnegård 2010. This approach to citation by monastic authorities would certainly have blurred any clear distinction between biblical text and biblical interpretation within their monasteries-the elder's interpretation became scripture. Accordingly, the monastic use of scripture may reflect what Gillian Lane-Mercier has called the "parodic" use of quotations, whereby "the listener is...manipulated into tacitly recognizing and sanctioning the authenticity of the quote" (Lane-Mercier 1991, 209). For Lane-Mercier, such approaches to quotation establish the social power of the speaker over against his or her audience (Lane-Mercier 1991, 206-207). 
or demonstrate their adroit abilities to excerpt select passages from the Bible and apply those passages in unique-and sometimes counterintuitive-ways to specific ascetic concerns. ${ }^{76}$ This evidence from monastic contexts demonstrates that creative reimagining and reinterpretation of biblical lore in light of contemporary situations was an important aspect of the Bible's reception during late antiquity, more generally. ${ }^{77}$

\section{III.2 The Complexity in Biblical Reception and the Use of Names for Ritual Power}

The complexity in the reception of the Bible that I just discussed ought to have direct bearing on how we imagine the character of metonymic reference to biblical materials in ritual contexts. ${ }^{78}$ Specifically, I argue that, given the impulse in late antiquity (and beyond) to expand on biblical materials as well as the porous boundary separating canonical and non-canonical traditions that overlap in content, we should not necessarily assume a simple part-for-whole (pars-pro-toto) relationship between metonymic "trigger" (the [abbreviated] biblical item cited) and "target” (the materials invoked).$^{79}$ In fact, Brit. Lib. Or. 6796(4), 6796 itself complicates facile notions of metonymic reference. As I noted above, the vowels $\mathrm{de \textrm {H }}$, which are written inside the crown of Jesus (1. 57), likely reference metonymically the entire sequence of seven vowels. But this explanation of the metonymic reference tells only part of the story. In fact, since this same practitioner links the seven vowels with the creative power of God (Brit. Lib. Or. 6796[2], 1. 65-69) and notes that they are written on the father's chest (Brit. Lib. Or. 6794, 11. 40-42), the simple claim that they invoke the seven vowels probably misses the point. I would argue that it is precisely these (and perhaps other) associations with the vowels-and not the vowels themselves-that stand at the heart of the ultimate metonymic reference. Given the nature

76 On the interpretive strategies of monks in scriptural debates with demons and heretics, see Clark 1999, 128-32; Sanzo 2014a, 56-61. To the extent that traditions associated with such figures were known, it is likely that these traditions would have at least colored the interpretation of biblical texts for their readers.

77 It is interesting to note that this monastic approach to the scriptures may have direct significance for the discussion at hand since recent scholarship has identified monasteries as among the primary institutional spaces for the creation of amulets and formularies during late antiquity (see n. 34 above).

78 Metonymy traditionally has been defined as a figure of speech in which one term is used to refer to another based on contiguity or association, and it is often exemplified in the part-for-whole relation. Metonymy, however, has been the subject of considerable discussion in the field of cognitive linguistics. For discussions of metonymy within cognitive linguistics, including its relation to other linguistic domains (e. g., synecdoche), see e.g., Seto 1999; Benczes, Barcelona, and Ruiz de Mendoza Ibáñez 2011.

79 On the problems associated with the part-for-whole model as it relates to the amuletic use of the Gospel incipits, see Sanzo 2014a, 151-61. 
of biblical reception during late antiquity, this complexity in metonymic reference almost certainly extended to the ritual use of other significant biblical elements, including the name "Jesus Christ." 80

In a related discussion, Sarah Iles Johnston has recently highlighted the various kinds of associations inherent in the names Demeter, Persephone, and Hades-the primary characters found in the various "Demeter myths." 81 As Johnston demonstrates, the name "Demeter" itself carried inherent associations with agriculture; at the same time, the names "Hades" and "Persephone" in and of themselves were able to evoke such strong sentiments of menace that they were avoided in many ritual contexts. ${ }^{82}$ According to Johnston, these and other cultural evocations are endemic to long-standing and far-reaching narratives-what she calls "myths." 83 In Johnston's words:

...by drawing its actors from a pool of characters whose names are already associated with wellknown histories and personalities, a myth is able to gesture toward a great deal more than it states; it can invoke ideas or themes that need not (and sometimes should not) be made explicit. $^{84}$

For Johnston, therefore, "myth" has a special capacity to reference metonymically a wide range of associations on account of the pervasiveness of its characters and other narrative elements within its cultural context.

Johnston's approach to myth certainly has implications for metonymic reference as it pertains to the apotropaic, exorcistic, and curative uses of names, especially names of famous figures associated with long-standing traditions. ${ }^{85}$ In particular, her contention that mere references to the names Demeter, Persephone, and Hades could "gesture toward" a wide range of cultural associations adds another layer of complexity to invocations of the name "Jesus (Christ)" on amulets and recipes, particularly when the name is mentioned with little nuance. ${ }^{86}$ For instance, in PGM IV.3007-46-a recipe from "Pibechis" for the demon-possessed-we find the follow-

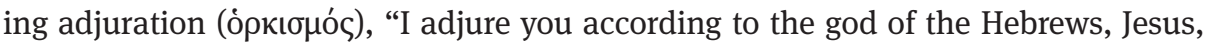

80 On Greek amulets that utilize the name Jesus, see de Bruyn 2010b. In my essay, I am not concerned with the use of onomata barbara and related naming practices in ancient "magic." For a discussion of the magical power of such names, see Gordon 2002, 76-81.

81 Johnston 2013. As Johnston highlights, there was no Ur-myth of Demeter (Johnston 2013, 373).

82 Johnston 2013, 391. Johnston argues that the euphemistic names also carried these associations; however, for Johnston, euphemistic names "privileged the gods' milder sides" (Johnston 2013, 391). 83 Johnston argues that such evocations are not present in novels since their characters are not as well known (Johnston 2013, 394).

84 Johnston 2013, 393.

85 Johnston suggests that evocations were associated with other "mythic" figures (Johnston 2013, $395-99)$.

86 See also Johnston's contribution to this volume. On the philosophical speculations about names by certain Jews and Christians during late antiquity, see Janowitz 2002, 19-43. 


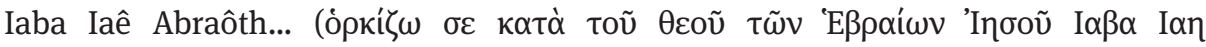
'A $\beta \alpha \omega \omega \theta . ..) . " 87$ This adjuration is the first in a series of several adjurations, which, when taken together, cross the scholarly boundaries between "Jewish," "Christian," and "Pagan" ritual practices. ${ }^{88}$ What I would like to emphasize for the concerns at hand is that the use of the name Jesus in this recipe suggests that the practitioner associated him (and the others), in some way, with exorcism. Another example is the simple use of Jesus Christ on P. Oxy. VIII 1152, an amulet from fifth-or sixth-century CE Oxyrhynchus: "Hôr, Hôr, Phôr, Elôei, Adônai, Iaô, Sabaôth, Michaêl, Jesus

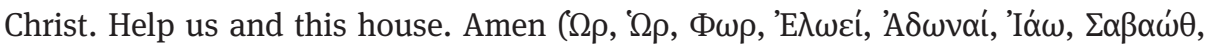

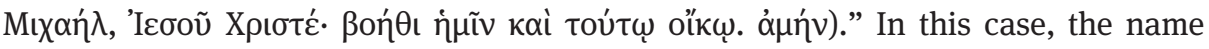
Jesus Christ (among other names) must have evoked notions of divine assistance and probably protection. But both of these examples raise a basic, but important, question: how did the name Jesus (Christ) relate to exorcism and/or protection?

In order to answer this question, it is instructive to reflect on the "magical" use of myth. In his classic analysis of the magical historiola, David Frankfurter offered a three-tiered approach to myth:

[myth is] (1) the abstract set of concepts and relations that might crystallize around or into (2) certain figures, names, places, or folklore motifs according to a culture's current circumstances, and then come into being within (3) a variety of performative settings according to a variety of forms that range from priestly liturgy...to scribal mythography...to historiolae, drama, sculpture, or painting. ${ }^{89}$

To appropriate this model for the present discussion, the use of the name Jesus Christ in a ritual performance (tier three) is contingent upon culturally specific articulations (tier two) of abstractions, such as divine protection (tier one or the "myth"). It is Frankfurter's tier two that is of special interest for my present concerns. For Frankfurter, cultural manifestations of abstract myths (tier two) provide an "authoritative discourse of precedent." ${ }^{0}$ From this perspective, therefore, Jesus and the other names mentioned in PGM IV.3007-46 and P. Oxy. VIII 1152 offer culturally authoritative precedents of the "myth," presumably that the divine has power over the demonic world. Yet the name Jesus Christ can only offer a meaningful precedent-by definition-in relation to specific events or settings. ${ }^{91}$ To invoke Jesus Christ, therefore, is

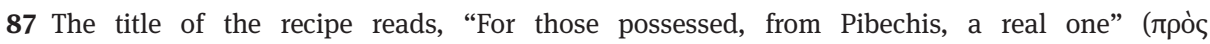

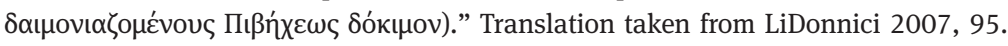

88 On the problems with classifying this recipe as "Jewish," "Christian, "Pagan," see Knox 1938, 198; LiDonnici 2007, 95-99. For general problems with classifying ritual artifacts in accordance with language of religious identification, see LiDonnici 2007, 107-108; Sanzo 2014a, 10-14. For analysis of the seal of Solomon, which is among the elements conjured in this recipe, see the paper by Ra'anan Boustan and Michael Beshay in this volume.

89 Frankfurter 1995, 474.

90 Frankfurter 1995, 475.

91 On the intersection of divine names, ritual power, and aretalogy on amulets, see Vikan 2008, 56; Luijendijk 2014b, 423-35. 
not simply to invoke a name or even the person/divinity (in an abstract sense), ${ }^{92}$ but also to summon authoritative precedents-connected with the name-that have analogical value for the present situation. ${ }^{93}$ In this vein, the inclusion of the name Jesus Christ on a given ritual text bears witness not only to abstract associations, such as protection or healing, but also to tacit precedents that impregnated these abstractions with concrete relevance and significance. ${ }^{94}$

But the use of the name Jesus Christ for apotropaic, curative, or exorcistic purposes likely "worked" in conjunction with traditions about him that would be unrecognizable to us. Indeed, the creative interpretation of the crucifixion story on Brit. Lib. Or. 6796(4), 6796 ought to remind us that the traditions, which buttressed the name Jesus Christ, probably did not always correspond with our canonical stories in a one-to-one fashion. Rather, all indications suggest that the name Jesus could be linked to past episodes from his life and ministry-derived, inter alia, from the biblical or parabiblical sources, ritual settings (e.g., the liturgy), the mind of the practitioner-or perhaps could even be connected with contemporary or recently past "real life" stories in which Jesus was believed to have healed such-and-such a client. Indeed, the juxtaposition of Jesus' name with the various divine names in PGM IV.3007-46 and P. Oxy. VIII 1152 (referenced above) is indicative of a complex and creative world of evocations and, consequently, metonymic references that only partially intersects with our canonical Gospels. ${ }^{95}$

\section{Conclusions}

In this paper, I examined the crucifixion tradition as presented on Brit. Lib. Or. 6796 (4), 6796. I first highlighted how the ritual specialist who produced this text created an innovative and highly complex weave of traditions; the practitioner not only juxtaposed diverse elements from the canonical Gospels, but he or she also incorporated a host of elements from non-canonical sources and even manufactured new details out of whole cloth. Having demonstrated the complexity and creativity of Brit.

92 Thus, the names do more than merely "stand for" the entity (cf. Janowitz 2002, 24).

93 For the importance of analogy in "magical” rituals, see Sørensen 1984; Schneider 2000; Salzer 2010.

94 Johnston likewise notes that a well-known name has the capacity to evoke "a core of collectively shared history and traits that lie behind the name" (Johnston 2013, 394).

95 In my estimation, therefore, there was considerable overlap between the ritual function of Jesus' name and that of the Gospel incipits (for discussion, see Sanzo 2014a, 151-61). Differences between these ritual practices were probably limited to issues of emphasis and/or additional associationsperhaps the dimension of the authority of scripture was stressed more forcefully in the case of the Gospel incipits, while the person of Jesus was more proximate and viscerally marked in the case of the ritual use of his name. Such possible differences in emphasis notwithstanding, both were concerned primarily with Jesus and both operated-at least in part-analogically on the basis of stories about him, some of which may be unrecognizable to us. 
Lib. Or. 6796(4), 6796, I then commented on the relationship between authoritative traditions and metonymy in so-called "magical" contexts. I argued that the manifold ways that ritual specialists engaged with biblical traditions, exemplified by Brit. Lib. Or. 6796(4), 6796, suggests that biblical traditions would have also been invoked in complex and unpredictable ways. Thus, we should not presume that the precedents that were invoked by the name Jesus Christ would have always corresponded to canonical pericopes or even to other traditions known to scholars. In fact, much of the evidence points in the opposite direction-to a realm of evocation and metonymic reference that only occasionally overlaps with traditions as they have been handed down to us.

On a more general level, the forgoing analysis has sought to demonstrate that there was a certain hermeneutical and evocative instability to at least some well-established and authoritative traditions during late antiquity that-perhaps ironicallywas tied to their ubiquity and authority. As "magical” artifacts and monastic literature teach us, popularity and significance do not necessarily enshrine a tradition or its original meaning, but may actually increase a tradition's susceptibility for reinterpretation and even creative reimagining-albeit within socially contingent frameworks. ${ }^{96}$ In this sense, authoritative traditions may represent the reverse of the Pauline slogan: when they are strong they are weak (cf. 2 Cor 12:10).

96 As Elizabeth Clark notes, “'high' texts...encourage the proliferation of meaning beyond authorial intention” (Clark 2004, 158). 
Appendix:

\section{Translation of Brit. Lib. Or. 6796(4), $6796^{97}$}

\section{Section 1: Trishagion and Prayer of Jesus on the Cross (ll. 1-10)}

[Holy, ${ }^{98}$ Ho]ly, Holy. ${ }^{99}$

The prayer of Jesus Christ that he proclaim![ed upon] the cro[s]s, cryi[ng out] (and) saying, "Elôei ${ }^{100}$ | [Elôei La]m[a Saba]ktani Marmarimari,"101 that is | "God, my god, why have you abandoned me?" Some of them ${ }_{I I}^{\prime(5)}$ [s]aid, "Elias," others, "Jeremias." One | of [t]hem took a sponge and dipped it in vinegar, and he (Jesus) took a taste. ' He said, "My father, all things have been com[plet]ed," and at once he gave up | the spirit. Heaven opened, the earth quaked, and the bo[nes] of those who had ! $\mathrm{d}[\mathrm{i}] \mathrm{ed}$ arose. In their bodies they went to Jerusalem, and they went (back) ${ }_{i I}{ }^{(10)}$ into the tomb.

\section{Section 2: Jesus and the Unicorn (Il. 10-23)}

I am Jesus Christ. I took to myself a $\mid$ cup of water in my hand and gave an invocation over it $\mid$ in the name of Marmarthi, ${ }^{102}$ the force (Arwamic) which stands before $\mid$ the father, the great power (сом) of Barbaraôth, the right ! [forear]m of Baraba, the cloud of light which stands $\| 1_{1}^{(15)}$ before Iaô Sabaôth. So I poured my cup | of water down into the sea, and it divided in the middle. I looked | down and saw a unicorn (папітап моүшт), who was lying on a golden | field; the one (the unicorn) who is named Sappathai. ${ }^{103}$

97 The following translation is a slightly modified version of Marvin Meyer's translation of Brit. Lib. Or. 6796(4), 6796 in Meyer and Smith 1994, 290-92. In order to avoid confusing line numbers with footnotes, I have placed line numbers in parentheses in intervals of 5.

98 Kropp postulated that cpc was written immediately before the Trishagion on Brit. Lib. Or. 6796(4) (Kropp 1931a, 47). Meyer followed Kropp in this assumption (Meyer and Smith 1994, 290). It should be highlighted, however, that there are no traces of these characters in the manuscript-at least not in its current state of preservation. Nevertheless, there is a sequence of visible decorative lines above the written text on Brit. Lib. Or. 6796(4).

99 Meyer translates the Trishagion here back into Latin, "[Sanctus, Sanctus], Sanctus” (Meyer and Smith 1994, 290).

100 Meyer's translation incorrectly reads, "Eloi” (Meyer and Smith 1994, 290).

101 See n. 24 above.

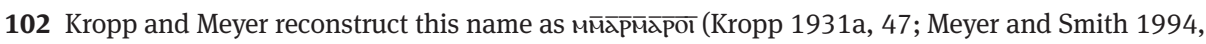
290); however, traces of the horizontal line of the theta are visible in the manuscript.

103 Since both "unicorn" (папїтап моүшт) and "field" (гої) are masculine, it is not entirely clear

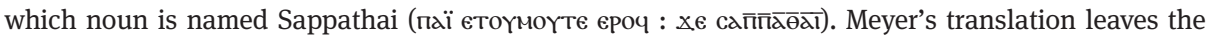
matter unresolved: "...a unicorn lying on a golden field that is named Sappathai" (Meyer and Smith 1994, 290). My translation reflects Kropp's plausible view that the "unicorn" is "Sappathai" (Kropp 1931, 16, §18). 
He spoke | to me, saying, "Who are you? If thus you stand ${ }_{\| \prime}{ }^{(20)}$ in this body or this flesh, you have not been given into my hand."

I spoke | to him saying, "I am I(sra)êl Êl, the force (_үмамıc) of Iaô | Sabaôth, the great power (бом) of Barbaraôth.”

So he ! hid himself from before me.

\section{Section 3: Invocations (ll. 23-30)}

By $(2 \bar{N})^{104}$ the power of the six other names that $\mid$ the father uttered over the head of his beloved son when he was hanged II ${ }^{(25)}$ upon the cross, saying, "My true name is Pharmen | Eiboubar Sich Tach Saba Chirinou.”

By the power | of Heretimos, by the power of Hikousad, by the power of Harmichousad, | by the power of Pharmen, the messenger of the father, by the power of | Senkeber Kankitha, by the power of Orphaneutê and the power ${ }_{11}^{(30)}$ of Orphamiêl, the great finger of the right hand of the father. !

\section{Section 4: Adjuration of the Father and Various Angels (Il. 31-45)}

Arouse yourself, father, in the seventh heaven and the fourteenth | firmament, and send me Jesus Christ, your only begotten son, i that he may seal my body and this bowl (6ג入д2T), ${ }^{105}$ for what you will bless | will be under the blessing, that he may cast out every ${ }_{11}^{(35)}$ unclean spirit of the defiled aggressor, from a hundred years | downward and twenty-one miles around, whether | a male demon (т̣емом) or a female demon (темом), whether a male $\left.\right|^{(6796)}$ potion $^{106}$ or a female $\mid$ spell, or a demon that is empty, ignorant, $\|^{(10)}$ defiled.

I adjure you, father, by Orpha, that is I your entire body, and Orphamiêl, that is the great finger | of your right hand, that you send me Jesus Christ | and the seven archangels, whose names are | Michaêl, Gabriêl, Suriêl, Asuêl, Raguêl, II ${ }^{(45)}$ Raphaêl, Saraphuêl. !

\section{Section 5: The Offering (ll. 46-48)}

O(ffering): charcoal from olive wood; | censer of white clay; genuine (olive) oil for a lamp; wild frankincense; | wild mastic; gourd; storax; calamus extract. |

104 In this section, Marvin Meyer translates the preposition $2 \overline{\mathrm{N}}$ as "in" (Meyer and Smith 1994, 290); however, I think the English "by" communicates more effectively the mechanistic sense of $2 \overline{\mathrm{N}}$ here. 105 Cf. 1. 49.

106 It should be noted that, contrary to this translation, Brit. Lib. Or. 6796(4) ends with фармако̄ and Brit. Lib. Or. 6796 begins with $\overline{\mathrm{N}} 200 \mathrm{\gamma}$. This discrepancy between text and translation, of course, simply reflects distinctions between Coptic and English syntaxes. 


\section{Section 6: The Preparation of the Bowl (Il. 49-52)}

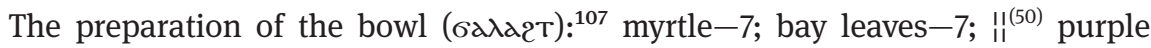
mint (?); baked (safflower?) mint; thorns (?)-7; virgin | palm leaves-7; wood of Abraham-7; garland or Artemisia | upon the bowl. !

\section{Section 7: The Drawing of the Crucifixion and Names in Ring-script (ll. 53-59) ${ }^{108}$}

(with rings) J(ESU)S C(HRIS)T | BÊTH BÊTHA ॥| ${ }^{(55)}$ BÊTHA IAÔ SABAÔTH ADÔNAI | ELÔEIU MICHAÊL GABRIÊL RAPHAÊL SURIÊL ASOUÊL RAGOUÊL SARAPHUÊL

\section{((drawing of crucifixion)}

(title on the cross)

| The king

(on the crown:)

$\mathrm{AEE}$

(name of thieves:)

| Gêstas | Dêmas

\section{Section 8: Final Instructions (ll. 60-65)}

III (60) Troglodytic myrrh. !

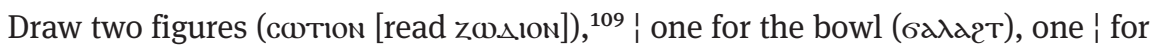
your neck.

Bricks: three, | under the bowl without handles. Purity. Put ${ }_{11}^{\prime(65)}$ royal salt around you.

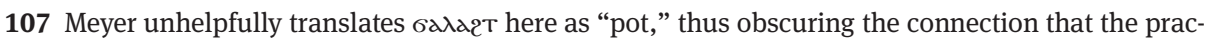
titioner makes between the балдгт in 1.33 that Jesus is supposed to seal (along with the client's body) and the 6алдгт here that is to be prepared (Meyer and Smith 1994, 291).

108 In order to avoid unnecessary confusion, I follow Kropp's line numbers for this section (Kropp 1931a, 49; Meyer and Smith 1994, 291); however, it should be noted that Kropp divided the lines in this section rather arbitrarily.

109 This spelling is also used on Brit. Lib. Or. 6795, 1. 46 (пексотток). 


\section{References}

Benczes, Réka, Antonio Barcelona, and Francisco José Ruiz de Mendoza Ibáñez, eds. 2011. Defining Metonymy in Cognitive Linguistics. Amsterdam: John Benjamins Publishing Company.

Biondi, Alessandro. 1979. "Le citazioni bibliche nei papiri magici cristiani greci." Studia Papyrologica 20:93-127.

Blanshard, Alastair. 2007. "The Problems with Honouring Samos: An Athenian Document Relief and its Interpretation." In Art and Inscriptions in the Ancient World, edited by Zahra Newby and Ruth Leader-Newby, 19-37. Cambridge: Cambridge University Press.

Bohak, Gideon. 2008. Ancient Jewish Magic: A History. Cambridge: Cambridge University Press.

Brakke, David. 2006. Demons and the Making of the Monk. Cambridge: Harvard University Press.

Brakke, David, ed. and trans. 2009. Evagrius of Pontus. Talking Back, Antirrhêtikos: A Monastic Handbook for Combating Demons. Collegeville: Liturgical Press.

Brashear, William. 1995. The Greek Magical Papyri: An Introduction and Survey; Annotated Bibliography (1928-1994)." In Aufstieg und Niedergang der römischen Welt. Vol. II.18.5, Heidentum: Die religiösen Verhältnisse in den Provinzen (Forts.), edited by Wolfgang Haase, 3380-684. Berlin: Walter de Gruyter.

Burton-Christie, Douglas. 1993. The Word in the Desert: Scripture and the Quest for Holiness in Early Christian Monasticism. New York: Oxford University Press.

Camplani, Alberto. 2010. “'Eli, Eli, lema sabachtani’: Pluralità dei linguaggi religiosi e loro rielaborazione rituale in alcune preghiere magiche copte." Studi e Materiali di Storia delle Religioni 76:139-150.

Clark, Elizabeth A. 1999. Reading Renunciation: Asceticism and Scripture in Early Christianity. Princeton: Princeton University Press.

Clark, Elizabeth A. 2004. History, Theory, Text: Historians and the Linguistic Turn. Cambridge, MA: Harvard University Press.

Collins, Derek. 2008a. Ancient Greek Magic. Malden: Blackwell.

Collins, Derek. 2008b. "The Magic of Homeric Verses." Classical Philology 103:211-36.

Cox Miller, Patricia. 1986. "In Praise of Nonsense." In Classical Mediterranean Spirituality, edited by A. Armstrong, 481-505. New York: Crossroad.

Daniel, Robert, and Franco Maltomini, eds. 1988. From the African Psalter and Liturgy." Zeitschrift für Papyrologie und Epigraphik 74:253-65.

Daniel, Robert, and Franco Maltomini, eds. 1990. Supplementum Magicum. Vol 1. Opladen: Westdeutscher Verlag.

De Bruyn, Theodore S. 2008. "Appeals to Jesus as the One "Who Heals Every Illness and Every Infirmity' (Matt 4:23, 9:35) in Amulets in Late Antiquity." In The Reception and Interpretation of the Bible in Late Antiquity: Proceedings of the Montréal Colloquium in Honour of Charles Kannengiesser, 11-13 October 2006, edited by Lorenzo DiTommaso and Lucian Turcescu, 65-81. Leiden: Brill.

De Bruyn, Theodore S. 2010a . "Papyri, Parchment, Ostraca, and Tablets Written with Biblical Texts in Greek and Used as Amulets: A Preliminary List." In Early Christian Manuscripts: Examples of Applied Method and Approach, edited by Thomas J. Kraus and Tobias Nicklas, 145-89. Leiden: Brill.

De Bruyn, Theodore S. 2010b. "Ancient Applied Christology: Appeals to Christ in Greek Amulets in Late Antiquity." In From Logos to Christos: Essays in Christology in Honour of Joanne McWilliam, edited by E. Leonard and K. Merriman, 3-18. Waterloo: Wilfrid Laurier University Press. 
De Bruyn, Theodore S., and Jitse H. F. Dijkstra. 2011. "Greek Amulets and Formularies from Egypt Containing Christian Elements: A Checklist of Papyri, Parchments, Ostraka, and Tablets." Bulletin of the American Society of Papyrologists 48:159-214.

Dickie, Matthew. 1999. "The Learned Magician and the Collection and Transmission of Magical Lore." In The World of Ancient Magic: Papers from the First International Samson Eitrem Seminar at the Norwegian Institute at Athens 4-8 May 1997, edited by David R. Jordan, Hugo Montgomery, Einar Thomassen, 163-93. Bergen: The Norwegian Institute at Athens.

Dieleman, Jacco. 2005. Priests, Tongues, and Rites: The London-Leiden Magical Manuscripts and Translation in Egyptian Ritual (100-300 CE). Leiden: Brill.

Elliott, J. K. 2000. A Bibliography of Greek New Testament Manuscripts. $2^{\text {nd }}$ ed. Cambridge: Cambridge University Press.

Fauth, Wolfgang. 2014. Jao-Jahwe und seine Engel: Jahwe-Appellationen und zugehörige Engelnamen in griechischen und koptischen Zaubertexten. Tübingen: Mohr Siebeck.

Fiaccadori, Gianfranco. 1986. "Cristo all' Eufrate (P. Heid. G. 1101, 8 ss.)." La parola del passato 41:59-63.

Foley, John Miles. 1991. Immanent Art: From Structure to Meaning in Traditional Oral Epic. Bloomington: Indiana University Press.

Frankfurter, David. 1994. "The Magic of Writing and the Writing of Magic: The Power of the Word in Egyptian and Greek Traditions." Helios 21:189-221.

Frankfurter, David. 1995. "Narrating Power: The Theory and Practice of the Magical Historiola in Ritual Spells." In Ancient Magic and Ritual Power, edited by Marvin W. Meyer and Paul A. Mirecki, 457-76. Leiden: Brill.

Frankfurter, David. 1997. "Ritual Expertise in Roman Egypt and the Problem of the Category 'Magician.' In Envisioning Magic: A Princeton Seminar and Symposium, edited by Peter Schäfer and Hans G. Kippenberg, 115-35. Leiden: Brill.

Frankfurter, David. 2002. "Dynamics of Ritual Expertise in Antiquity and Beyond: Towards a New Taxonomy of 'Magicians."' In Magic and Ritual in the Ancient World, edited by Paul Mirecki and Marvin Meyer, 159-78. Leiden: Brill.

Gordon, Richard. 2002. "Shaping the Text: Innovation and Authority in Graeco-Egyptian Malign Magic." In Kykeon: Studies in Honour of H. S. Versnel, edited by H. F. J. Horstmanshoff, H. W. Singor, F. T. van Stratten, and J. H. M. Strubbe, 69-111. Leiden: Brill.

Graf, Fritz. 1999. Magic in the Ancient World. Cambridge: Harvard University Press.

Graham, William A. 1987. Beyond the Written Word: Oral Aspects of Scripture in the History of Religion. Cambridge University Press.

Haines-Eitzen, Kim. 2000. Guardians of Letters: Literacy, Power, and the Transmitters of Rarly Christian Literature. New York. Oxford University Press.

Hays, Richard B. 1989. Echoes of Scripture in the Letters of Paul. New Haven: Yale University Press.

Head, Peter. 2012. "Additional Witnesses to the New Testament (Ostraca, Amulets, Inscriptions, and Other Sources). In The Text of the New Testament in Contemporary Research: Essays on the Status Quaestionis, edited by M. W. Holmes and B. D. Ehrman, 429-460. Leiden: Brill.

Hill, Charles E. 2012. "'In These Very Words': Methods and Standards of Literary Borrowing in the Second Century." In The Early Text of the New Testament, edited by Charles E. Hill and Michael J. Kruger, 261-81. Oxford: Oxford University Press.

Hunt, Arthur S. 1911. "Christian Amulet." In The Oxyrhynchus Papyri. Vol. 8, edited by Arthur S. Hunt, 253. London: Egypt Exploration Society.

Izydorczyk, Zbigniew. 1997. "Introduction." In The Medieval Gospel of Nicodemus: Texts, Intertexts, and Contexts in Western Europe, edited by Zbigniew Izydorczyk, 1-19. Tempe: Arizona Board of Regents for Arizona State University. 
Izydorczyk, Zbigniew, and Jean-Daniel Dubois. 1997. "Before and Beyond the Medieval West." In The Medieval Gospel of Nicodemus: Texts, Intertexts, and Contexts in Western Europe, edited by Zbigniew Izydorczyk, 21-41. Tempe: Arizona Board of Regents for Arizona State University. Janowitz, Naomi. 2002. Icons of Power: Ritual Practices in Late Antiquity. University Park: The Pennsylvania State University Press.

Johnston, Sarah Iles. 2008. "Animating Statues: A Case Study in Ritual." Arethusa 41:445-77.

Johnston, Sarah Iles. 2013. "Demeter, Myths and the Polyvalence of Festivals." History of Religions 52:370-401.

Jones, Brice C. 2015. "New Testament Texts on Greek Amulets from Late Antiquity and Their Relevance for Textual Criticism." PhD diss., Concordia University.

Judge, E. A. 1987. "The Magical Use of Scripture in the Papyri." In Perspectives on Language and Text: Essays and Poems in Honor of Francis I. Andersen's Sixtieth Birthday July 28, 1985, edited by Edgar W. Conrad and Edward G. Newing, 339-49. Winona Lake: Eisenbrauns.

Kim, H. C., ed. 1973. The Gospel of Nicodemus: Gesta salvatoris. Toronto: Pontifical Institute of Medieaval Studies.

Knox, W. L. 1938. “Jewish Liturgical Exorcism.” Harvard Theological Review 31:191-203.

Kraus, Thomas J. 2005. "Septuaginta-Psalm 90 in apotropäischer Verwendung: Vorüberlegungen für eine kritische Edition und (bisheriges) Datenmaterial." Biblische Notizen 125:39-73.

Kraus, Thomas J. 2006. "Manuscripts with the Lord's Prayer-They are More than Simply Witnesses to that Text Itself." In New Testament Manuscripts: Their Texts and their World, edited by Thomas J. Kraus and Tobias Nicklas, 227-66. Leiden: Brill.

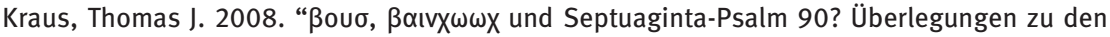
sogennanten 'Bous'-Amuletten und dem beliebtesten Bibeltext für apotropäische Zwecke.” Zeitschrift für antikes Christentum 11:479-91.

Kristeva, Julia. 1980. "Word, Dialogue and Novel." In Desire in Language: A Semiotic Approach to Language and Art, edited by L. S. Roudiez and translated by T. Gora, A. Jardine, and L. S. Roudiez, 64-91. New York: Columbia University Press.

Kropp, Angelicus, ed. 1930. Ausgewählte koptische Zaubertexte. Vol. 3, Einleitung in koptische Zaubertexte. Brussels: Édition de la Fondation égyptologique Reine Élisabeth.

Kropp, Angelicus, ed. 1931a. Ausgewählte koptische Zaubertexte. Vol. 1, Textpublikation. Brussels: Édition de la Fondation égyptologique Reine Élisabeth.

Kropp, Angelicus, ed. 1931b. Ausgewählte koptische Zaubertexte. Vol. 2, Übersetzungen und Anmerkungen. Brussels: Édition de la Fondation égyptologique Reine Élisabeth.

Lane-Mercier, Gillian. 1991. "Quotation as a Discursive Strategy." Kodikas 14:199-214.

Leonas, A. 1999. "The Septuagint and the Magical Papyri: Some Preliminary Notes." Bulletin of the International Organization for Septuagint and Cognate Studies 32:51-64.

LiDonnici, Lynn. 2007. “'According to the Jews:' Identified (and Identifying) 'Jewish' Elements in the Greek Magical Papyri." In Heavenly Tablets: Interpretation, Identity, and Tradition in Ancient Judaism, edited by Lynn LiDonnici and Andrea Lieber, 87-108. Leiden: Brill.

Lucas, Alec J. 2014. "Assessing Stanely E. Porter's Objections to Richard B. Hay’s Notion of Metalepsis." The Catholic Biblical Quarterly 76:93-113.

Luijendijk, AnneMarie. 2014a. Forbidden Oracles? The Gospel of the Lots of Mary. Tübingen: Mohr Siebeck.

Luijendijk, AnneMarie. 2014b. “A Gospel Amulet for Joannia (P.Oxy. VIII 1151)." In Daughters of Hecate: Women and Magic in the Ancient World, edited by Kimberly B. Stratton, Dayna S. Kalleres, 418-43. Oxford: Oxford University Press.

Maltomini, Franco. 1982. "Cristo all'Eufrate P. Heid.G.1101: Amuleto cristiano.” Zeitschrift für Papyrologie und Epigraphik 48:149-70. 
Malinowski, Bronistaw. 1965. "The Role of Magic and Religion." In Reader in Comparative Religion: An Anthropological Approach, edited by William A. Lessa and Evon Z. Vogt, 102-12. $2^{\text {nd }}$ ed. New York: Harper and Row.

Mazza, Roberta. 2007. “P.Oxy. XI, 1384: Medicina, rituali di guarigione e cristianesimi nell'Egitto tardoantico." Annali di storia dell'esegesi 24:437-62.

McVey, Kathleen. 1998. "The Chreia in the Desert: Rhetoric and the Bible in the Apophthegmata Patrum." In The early Church in its Context: Essays in Honor of Everett Ferguson, edited by Abraham J. Malherbe, Frederick W. Norris, and James W. Thompson, 245-55. Leiden: Brill.

Meek, Russell L. 2014. "Intertxtuality, Inner-Biblical Exegesis, and Inner-Biblical Allusion: The Ethics of a Methodology." Biblica 95:280-91.

Meyer, Marvin. 1996. The Magical Book of Mary and the Angels (P. Heid. inv. Kopt. 685): Text, Translation, and Commentary. Heidelberg: Universitätsverlag C. Winter.

Meyer, Marvin. 2002. "The Prayer of Mary Who Dissolves Chains in Coptic Magic and Religion." In Magic and Ritual in the Ancient World, edited by Paul Mirecki and Marvin Meyer, 407-15. Leiden: Brill.

Meyer, Marvin W., and Richard Smith, eds. 1994. Ancient Christian Magic: Coptic Texts of Ritual Power. San Francisco: Harper San Francisco.

Mirecki, Paul. 1994. “The Coptic Wizard's Hoard.” Harvard Theological Review 87:435-60.

Newby, Zahra. 2007. "Introduction." In Art and Inscriptions in the Ancient World, edited by Zahra Newby and Ruth Leader-Newby, 1-16. Cambridge: Cambridge University Press.

O'Ceallaigh, G. C. 1963. "Dating the Commentaries of Nicodemus." Harvard Theological Review 56:21-58.

Pietersma, Albert and Benjamin G. Wright. 2007. A New English Translation of the Septuagint and the Other Greek Translations Traditionally Included Under that Title. New York: Oxford University Press.

Pleše, Zlatko. 2006. Poetics of the Gnostic Universe: Narrative and Cosmology in the Apocryphon of John. Leiden: Brill.

Porter, Stanley. 2006. "Textual Criticism in the Light of Diverse Textual Evidence for the Greek New Testament: An Expanded Proposal." In New Testament Manuscripts: Their Texts and their World, edited by Thomas J. Kraus and Tobias Nicklas, 305-37. Leiden: Brill.

Richter, Siegfried. 2003. "Verwendung von Psalmen im koptischen Christentum." In Ritual und Poesie: Formen und Orte religiöser Dichtung im alten Orient, im Judentum und im Christentum, edited by Erich Zenger, 283-92. Freiburg: Herder.

Rönnegård, Per. 2010. "The Use of Scripture in Apophthegmata Patrum in Light of the Ergasia Pattern." In Papers Presented at the Fifteenth International Conference on Patristic Studies Held in Oxford 2007, Studia Patristica XLV, edited by J. Baun, A. Cameron, M. Edwards, and M. Vinzent, 35-41. Leuven: Peeters.

Salzer, Dorothea M. 2010. Die Magie der Anspielung: Form und Funktion der biblischen Anspielungen in den magischen Texten der Kairoer Geniza. Tübingen: Mohr Siebeck.

Sanzo, Joseph E. 2014a. Scriptural Incipits on Amulets from Late Antique Egypt: Text, Typology, and Theory. Tübingen: Mohr Siebeck.

Sanzo, Joseph E. 2014b. “'For our Lord was Pursued by the Jews...': The (Ab)use of the Motif of 'Jewish' Violence Against Jesus on a Greek Amulet (P. Heid. 1101)." In One in Christ Jesus: Essays on Early Christianity and "All that Jazz," in Honor of S. Scott Bartchy, edited by David Matson and K.C. Richardson, 86-98. Eugene, OR: Pickwick Publications.

Schneider, Thomas. 2000. "Die Waffe der Analogie: Altägyptische Magie als System.” In Analogiedenke: Vorstöße in ein neues Gebiet der Rationalitätstheorie, edited by M. Bachmann and K. Gloy, 37-85. Freiburg and München: Verlag K. Alber. 
Seto, Ken-Ichi. 1999. "Distinguishing Metonymy from Synecdoche." In Metonymy in Language and Thought, edited by Klaus-Uwe Panther and Günter Radden, 91-120. Amsterdam: John Benjamins Publishing Company.

Shandruk, Walter M. 2012. "Christian Use of Magic in Late Antique Egypt." Journal of Early Christian Studies 20:31-57.

Sijpesteijn, P. J. 1982. “Amulet Against Fever.” Chronique d’Égypt 57:377-81.

Sørensen, Jørgen Podemann. 1984. "The Argument in Ancient Egyptian Magical Formulae.” Acta Orientalia 45:5-19.

Squire, Michael. 2009. Image and Text in Graeco-Roman Antiquity. Cambridge: Cambridge University Press.

Squire, Michael. 2011. The Iliad in a Nutshell: Visualizing Epic on the Tabulae Iliacae. Oxford: Oxford University Press.

Vandoni, M., and T. Orlandi, eds. 1966. Vangelo di Nicodemo. Pt. 2, Traduzione dal copto e commentario. Milan: Instituto Editoriale Cisalpino.

Versnel, H. S. 2002. "The Poetics of the Magical Charm: An Essay in the Power of Words." In Magic and Ritual in the Ancient World, edited by Paul Mirecki and Marvin Meyer, 105-58. Leiden: Brill.

Vikan, Gary. 2008. "Magic and Visual Culture in Late Antiquity." In Greek Magic: Ancient, Medieval, and Modern, edited by J. C. B. Petropoulos, 53-57. London: Routledge.

Vitelli, G. 1928. "Noterelle papirologiche." Bulletin de la Société Archéologique d'Alexandrie 23:287-302.

Wasserman, Tommy. 2011. "The 'Son of God' Was in the Beginning (Mark 1:1)." Journal of Theological Studies 62:20-50.

Wilburn, Andrew T. 2012. Materia Magica: The Archaeology of Magic in Roman Egypt, Cyprus, and Spain. Ann Arbor: University of Michigan Press.

Worrell, William H. 1930. "A Coptic Wizard's Hoard." The American Journal of Semitic Languages and Literatures 46:239-62.

Zuntz, Gunther. 1953. The Text of the Epistles: A Disquisition Upon the Corpus Paulinum. London: Oxford University Press for the British Academy. 